\title{
Metabolic Remodelling: An Accomplice for New Therapeutic Strategies to Fight Lung Cancer
}

\author{
Cindy Mendes ${ }^{1,2}$ and Jacinta Serpa ${ }^{1,2, *(D)}$ \\ 1 CEDOC, Chronic Diseases Research Centre, NOVA Medical School, Faculdade de Ciências Médicas, \\ Universidade NOVA de Lisboa, Campo dos Mártires da Pátria, 130, 1169-056 Lisboa, Portugal; \\ cindymendes8@gmail.com \\ 2 Instituto Português de Oncologia de Lisboa Francisco Gentil (IPOLFG), Rua Prof Lima Basto, \\ 1099-023 Lisboa, Portugal \\ * Correspondence: jacinta.serpa@nms.unl.pt
}

Received: 30 October 2019; Accepted: 27 November 2019; Published: 29 November 2019

\begin{abstract}
Metabolic remodelling is a hallmark of cancer, however little has been unravelled in its role in chemoresistance, which is a major hurdle to cancer control. Lung cancer is a leading cause of death by cancer, mainly due to the diagnosis at an advanced stage and to the development of resistance to therapy. Targeted therapeutic agents combined with comprehensive drugs are commonly used to treat lung cancer. However, resistance mechanisms are difficult to avoid. In this review, we will address some of those therapeutic regimens, resistance mechanisms that are eventually developed by lung cancer cells, metabolic alterations that have already been described in lung cancer and putative new therapeutic strategies, and the integration of conventional drugs and genetic and metabolic-targeted therapies. The oxidative stress is pivotal in this whole network. A better understanding of cancer cell metabolism and molecular adaptations underlying resistance mechanisms will provide clues to design new therapeutic strategies, including the combination of chemotherapeutic and targeted agents, considering metabolic intervenients. As cancer cells undergo a constant metabolic adaptive drift, therapeutic regimens must constantly adapt.
\end{abstract}

Keywords: lung cancer; cancer metabolism; reactive oxygen species (ROS); therapy resistance; new therapeutic strategies

\section{Cancer Metabolism}

Although cancer metabolism is one of the oldest areas of research in cancer biology, the study of metabolic alterations in tumours has grown exponentially in the past decade [1,2]. The link between cancer and metabolism was first made by Otto Warburg in 1923 with the observation that most cancer cells predominantly produce energy through a high rate of glycolysis followed by lactic acid fermentation, rather than through oxidative phosphorylation (OXPHOS) in the mitochondria [3]. Thus, tumours exhibit an increased rate of glucose uptake with lactate production, even in the presence of oxygen, through aerobic glycolysis with the production of carbon skeletons, NADPH and ATP [4]. This glycolytic switch, known as the "Warburg effect", was first described as a compensation mechanism for mitochondria dysfunction in tumours. However, this view was challenged as several studies found that mitochondrial OXPHOS is active in most types of cancer [5-8]. To fulfil the biosynthetic demands associated with proliferation, mitochondria occupy a core status as providers of ATP and intermediate metabolites, such as citrate to supply anabolic reactions [9]. Moreover, in nontransformed cells, the Warburg effect is a reversible phenomenon linked to proliferation, showing that it reflects proliferation associated changes in metabolism instead of a unique feature of malignancy [10]. Glucose metabolism rewiring is more likely to be driven by an elevated demand 
of reducing equivalents and molecular precursors of proteins, nucleotides and lipids, which are the building blocks required to maintain cancer cell growth and proliferation [11]. Besides glucose, glutamine also contributes to core metabolic functions of cancer cells since it fuels the tricarboxylic acid (TCA) cycle, nucleotide and fatty acid biosynthesis and redox balance $[10,12]$, replacing completely glucose as a core organic compound.

Despite the fact that energetic metabolism is one of the cancer hallmarks, little has been shown in its role in chemoresistance [13]. Besides producing ATP, OXPHOS is the major source of reactive oxygen species (ROS) within mitochondria and in the entire cell [14]. During OXPHOS, the acetyl-CoA from glucose and fatty acids degradation feeds the TCA cycle, which generates reduced compounds $[10,12]$ that will transfer electrons to the OXPHOS system through a chain of redox reactions with the final reduction of oxygen to water. In some of these reactions, ROS is a by-product [15], changing the mitochondrial membrane potential (MPP) and inducing damages in the respiratory chain, pushing cells towards apoptosis [14]. In response to augmented ROS, many tumours trigger protective antioxidant pathways [16]. Glutathione (GSH), peroxiredoxins, thioredoxin and superoxide dismutase (SOD2) belong to the major antioxidant system, maintaining the redox homeostasis [17-19]. Thus, the activation of those ROS scavenging processes constitutes a mechanism of resistance to chemotherapy exhibited by cancer cells, upon the exposure to alkylating or ROS generator drugs [14]. Changes in endogenous metabolism influence the metabolic course of xenobiotic compounds, which includes drugs used in cancer therapy. This fact reinforces the role of cancer metabolic rewiring as crucial in cancer cells survival and response to therapy. Here, we will discuss the main features of cancer metabolism and its influence on therapy resistance in lung cancer.

\section{Metabolic Remodelling in Lung Cancer}

Lung cancer is a prevalent cause of cancer-related death [20], being grouped in two principal histological subtypes: small cell lung carcinoma (SCLC; $15 \%$ of total) and non-small-cell lung carcinoma (NSCLC; 85\% of total) [21]. NSCLC is classified into three histotypes: squamous-cell carcinoma, adenocarcinoma, and large-cell carcinoma [22]. Metabolism was shown to be differently reprogrammed in the major subtypes of non-small cell lung cancer [23]. Metabolic remodelling is one of the emerging hallmarks of cancer [24] and it is well recognised that cancer cells have a high metabolic plasticity to support continuous cell growth and proliferation, meeting their energetic and biomass demands [25]. Recent studies reported metabolic alterations in glucose, lipids, amino acids and nucleic acids metabolism in NSCLC cells (Figure 1).

In the past decade, stable-isotope tracing with ${ }^{13} \mathrm{C}$-glucose became an important tool for the analysis of metabolic pathways that are differentially activated in tumour cells in vivo, both in cancer mouse models and humans [26-30]. Uniformly labelled ${ }^{13} \mathrm{C}$-glucose is administered as a bolus by an intraoperative infusion before surgical tumour resection and the distribution of labelled carbons in the various intermediates is analysed by ${ }^{13} \mathrm{C}$ NMR spectroscopy [31,32]. A study using fresh surgical resections from NSCLC patients with mixed histology, after a labelled ${ }^{13} \mathrm{C}$-glucose infusion, showed contrasting glucose metabolism results; tumour samples displayed high levels of lactate, demonstrating an upregulation in glycolysis, but also increased levels of glucose-derived TCA cycle intermediates, in tumour samples compared with normal tissue [30]. These observations reinforce the fact that glycolysis and OXPHOS can function in simultaneous if not in the same cancer cell at least in the same tumour, in which metabolic symbiosis can be established. Hensley and colleagues combined multimodal imaging analysis (FDG-PET and multiparametric MRI) and ${ }^{13} \mathrm{C}$-glucose flux profiling of NSCLC in situ to provide quantitative information about glucose metabolism and the tumour microenvironment in NSCLC untreated patients [28]. The activity of PC (pyruvate carboxylase), the enzyme responsible for the conversion of pyruvate into oxaloacetate, was elevated in NSCLC tumours [28,33], and its silencing significantly decreased the proliferative and colony-forming capacity of NSCLC cell lineages and reduced tumour growth in murine xenograft models, suggesting a dependence on PC-mediated and TCA cycle-based anaplerosis [33]. Moreover, it was found that 
glycolysis and glucose oxidation via PDH (pyruvate dehydrogenase) and the TCA cycle were higher in NSCLC compared to the adjacent normal lung [28]. Glucose-derived metabolic intermediates can be synthesized directly from glucose or indirectly from glucose-derived lactate. This fact was demonstrated by Faubert et al. [29]; lactate is the main carbon source for the TCA cycle in tumours from NSCLC patients and tumour xenografts.

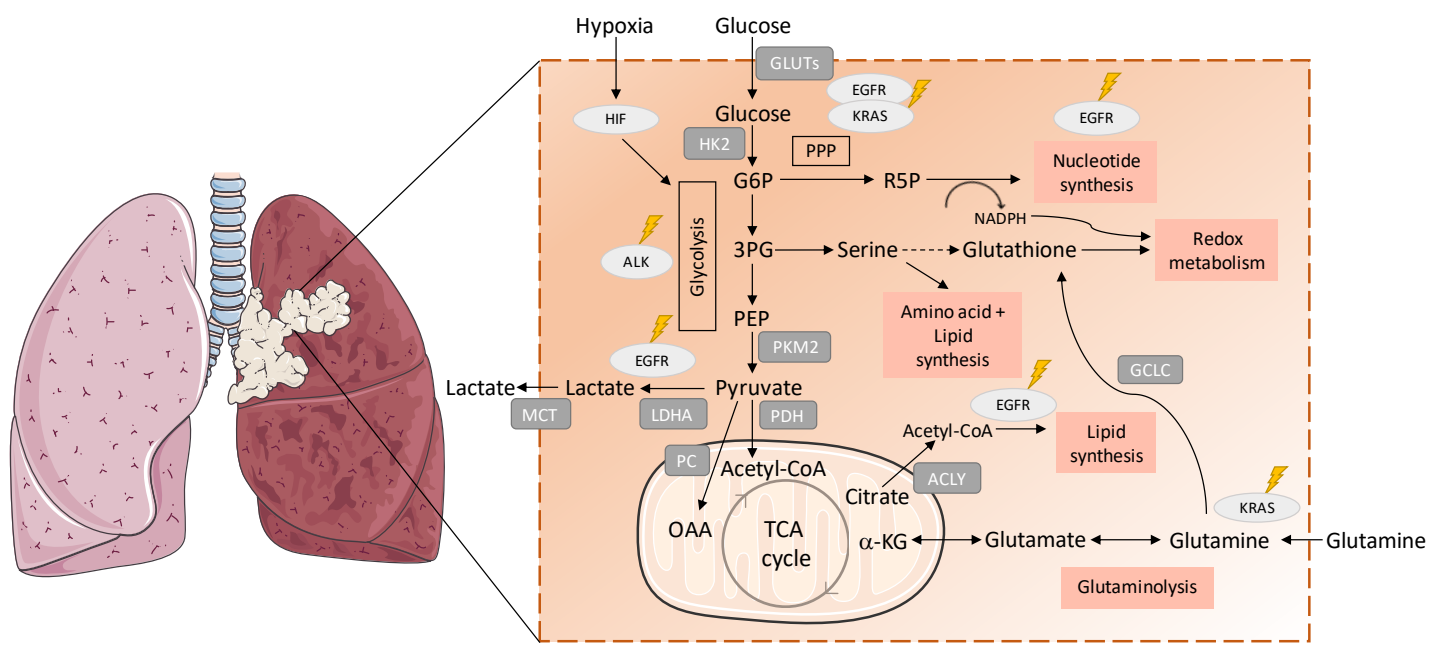

Figure 1. Metabolic remodelling in lung cancer. Metabolic pathways are involved in the synthesis of building blocks for macromolecules and redox homeostasis, needed for cell proliferation are presented. The import of glucose is mediated by the GLUT (glucose transporter) family of membrane transport proteins, which are known to be deregulated in cancer [34]. Hexokinase 2 (HK-2) is the first rate-limiting enzyme in the glycolytic pathway and overexpression of HK-2 has wildly been observed in cancer cells, correlating with poor overall survival in cancer patients [35-37]. Mutant EGFR (epidermal growth factor receptor 1) promotes metabolic remodelling in non-small-cell lung carcinoma (NSCLC) with increased aerobic glycolysis and PPP (pentose phosphate pathway), altered pyrimidine biosynthesis and upregulation of monounsaturated fatty acids [38-40]. KRAS (Kirsten rat sarcoma viral oncogene homolog GTPase)-mutated NSCLC cells express higher levels of enzymes involved in glycolysis, such as pyruvate kinase isozyme M2 (PKM2) and lactate dehydrogenase A (LDHA) compared with nonmalignant cells, indicating alterations in glucose metabolism and PPP (glicose-6-fosfato dehydrogenase (G6PD), transketolase (TKT) and 6-phosphogluconate dehydrogenase (6PGD)) [41]. Pyruvate is decarboxylated into acetyl-CoA to be further transported into mitochondria to enter the TCA cycle [42]. ALK (anaplastic lymphoma kinase) rearrangements were associated with upregulated glucose metabolism in highly metastatic phenotypes of adenocarcinoma [43]. The expression and activity of PC (pyruvate carboxylase), the enzyme responsible for the conversion of pyruvate into oxaloacetate, was found to be elevated in NSCLC tumours [28,33]. Glycolysis and glucose oxidation via PDH (pyruvate dehydrogenase) and the TCA cycle were enhanced in NSCLC comparing to adjacent benign lung [28]. Cancer cells also show higher levels of monocarboxylate transporters (MCT), which are responsible for lactate export and helps both in maintaining intracellular $\mathrm{pH}$ and in continuing glycolysis [44]. Hif-1 (hypoxia inducible factor 1) regulates the transcription of glycolytic enzymes such as, HK-2, LDH-A and PKM2, which upregulate glycolysis [45,46]. The expression of ATP citrate lyase (ACLY), a key enzyme in fatty acid synthesis was upregulated in NSCLC, being associated with poor prognosis [30]. Glutathione cysteine ligase (GCLC), which converts glutamate to Glutathione (GSH), is also highly expressed in several cancers, including lung cancer, and high mRNA expression of GCLC-promoted cisplatin resistance in lung adenocarcinoma cell lines [47]. G6P: glucose 6-phosphate; 3PG: 3-phosphoglyceric acid; PEP: phosphoenolpyruvate; R5P: ribose 5-phosphate; MCT: monocarboxylate transporters; OAA: oxaloacetate; $\alpha$-KG: alpha ketoglutarate.

Several enzymes and transporters, crucial for carbon and energy metabolism, have been described as differently expressed in a normal lung and in cancer. The expression of ATP citrate lyase (ACLY), 
a key enzyme in fatty acid synthesis involved in the synthesis of acetyl-CoA and oxaloacetate, was upregulated in NSCLC, being associated with poor prognosis [48]. Glycine decarboxylase (GLDC), which couples decarboxylation of glycine to the biosynthesis of serine and one-carbon metabolism, takes part in pyrimidine metabolism and is upregulated in NSCLC cells [49]. xCT (SLC7A11), a cystine/glutamate antiporter, is overexpressed in the plasma membrane in NSCLC, correlating with patients' worse survival [50]. Interestingly, it was described that cancer cells expressing high levels of $\mathrm{xCT}$ relied on glutamine and glutaminolysis dependency for OXPHOS [50]. This glutamine consumer phenotype may also be linked to cyst(e)ine dependency, as XCT concomitantly exports glutamate and imports cyst(e)ine. Glutamate is a direct product of glutamine degradation and maintaining the glutamine import sustains the import of cyst(e)ine, which has been related to increased therapy resistance in different cancer models [51], mostly due to its role in glutathione synthesis [52-55], for which glutamine-derived glutamate is also needed.

Despite similarities in metabolic reprogramming, the metabolic alterations in NSCLC cells or tumours are highly heterogeneous $[28,39,56]$. Hensley et al., identified metabolically heterogenous regions both within and between tumours, in which reduced perfusion tumour areas preferentially used glucose whereas well perfused regions relied more on non-glucose nutrients indicating that tumour metabolic remodelling is regulated by the microenvironment [28]. The generation of a hypoxic environment (oxygen deprivation) is a common feature of solid cancers as a consequence of the development of a disordered vasculature, which is not able to properly supply oxygen to a rapidly growing tumour [57]. Hypoxia is known to activate HIF signalling in cancer cells and plays an important role in the pathogenesis and prognosis of lung cancer [58]. Induction of HIF activity targets genes involved in glucose metabolism, angiogenesis, cell proliferation and resistance to therapies [59]. Furthermore, both Hif- $1 \alpha$ and Hif- $2 \alpha$ are frequently overexpressed in NSCLC correlating, in some cases, with poor prognosis $[60,61]$ and Hif- $1 \alpha$ expression is associated with resistance to cancer therapy, including EGFR (epidermal growth factor receptor 1) inhibitors in NSCLC [46].

Thus, understanding the influence of cellular or microenvironmental factors, such as oncogene-induced metabolic switches, on cancer cell metabolism is crucial for the development of better-adjusted therapeutic approaches targeting metabolic remodelling in cancer cells.

\section{Role of Oncogenic Mutations (EGFR, ALK, KRAS) in Metabolic Remodelling}

Certain genetic alterations have been shown as crucial in lung carcinogenesis. Mutations in EGFR (epidermal growth factor receptor 1) and KRAS (Kirsten rat sarcoma viral oncogene homolog GTPase) and $A L K$ (anaplastic lymphoma kinase) rearrangements are mostly found in lung adenocarcinoma, accounting for $30-40 \%$ of NSCLCs [62]. Mutations in these oncogenes have been shown to play a role in metabolic reprogramming of cancer cells to support their high proliferative rate and energetic demands [39,63].

Mutant EGFR promotes metabolic remodelling in NSCLC with increased aerobic glycolysis and PPP (pentose phosphate pathway), altered pyrimidine biosynthesis and redox metabolism [38,39]. Treatment with erlotinib (EGFR inhibitor) and a glutaminase inhibitor (CB-839) generates a metabolic crisis in EGFR mutant NSCLC cells, resulting in cell death and in rapid tumour regression in mouse NSCLC xenografts [64]. These facts indicate the need of glutamine as a source for bioenergetics and biosynthesis in EGFR-mutated NSCLCs, as glucose is mainly used to sustain PPP and consequently cancer cells proliferation. Another study, showed the role of EGFR in the stabilization by phosphorylation of stearoyl-CoA desaturase-1 (SCD1), augmenting monounsaturated fatty acid synthesis and sustaining cell proliferation [40]. In addition, phosphorylated SCD1 levels were reported as an independent prognostic factor for poor survival in NSCLC [40].

The influence of $A L K$ rearrangements on metabolism has not been well described in lung adenocarcinoma. However, a recent study observed the presence of upregulated glucose metabolism in highly metastatic phenotypes in this subset of lung cancer [43]. Again, increased consumption of glucose is linked to more aggressive cancer phenotypes. 
Numerous studies showed the involvement of mutant KRAS in the metabolic rewiring of different types of cancer $[63,65,66]$ with an upregulation of glucose uptake and aerobic glycolysis and increased glutamine utilization [67-69]. Proteomic profiles related to metabolism of intrinsic KRAS mutant NSCLC cell lines were investigated and compared with those of normal bronchial epithelial cells [41]. KRAS-mutated NSCLC cells expressed higher levels of enzymes involved in glycolysis (glyceraldehyde 3-phosphate dehydrogenase-GAPDH, pyruvate kinase isozyme M2-PKM2, lactate dehydrogenase A-LDHA and lactate dehydrogenase B-LDHB) and PPP (glicose-6-fosfato dehydrogenase-G6PD, transketolase-TKT and 6-phosphogluconate dehydrogenase-6PGD) compared with nonmalignant cells [41]. In another study, NSCLC cells carrying KRAS mutations showed metabolic remodelling with alterations in redox buffering systems and glutamine dependency [70]. Moreover, an upregulation of lactate production was observed in a mutant KRAS lung tumour mouse model [27], however, these mouse models minimally used glutamine as a carbon source for TCA cycle entry, while in the in vitro models, there was a dependence on glutamine. Thus, glutamine dependency can be related to the homeostatic cellular systems, such as GSH production, and not related to the direct and extensive used of glutamine as a carbon and energy source. In agreement with this, oxidative glucose metabolic enzymes, such as PC and PDH (pyruvate dehydrogenase), were shown to be necessary for tumour formation and growth in these mouse models [27]. Homozygous mutant KRAS cells have been shown to have an increased antioxidant capacity that accounts for their selective growth during lung tumour progression [63,71]. Varying oxygen levels within the growing tumour can contribute to this selection, since increased expression of Hif- $2 \alpha$ promotes tumour growth and malignant progression of KRAS ${ }^{\text {G12D }}$ lung tumours [72]. These results correlated with existing human clinical data, implicating Hif-2 $\alpha$ as a negative prognostic factor in human NSCLC [72].

\section{Lung Cancer Therapy}

Over the last 20 years, lung cancer treatment has evolved from the empiric use of cytotoxic therapies to effective and better tolerated targeted therapies. Platinum-based doublet therapy (combining platinum-based drugs with another cytotoxic/cytostatic agent) has been the standard therapy for both primary and palliative care of patients with advanced stage lung cancer $[73,74]$. Genotyping studies revealing genetic alterations in the various subtypes of lung cancer accounting for tumorigenesis led to the development of targeted therapies, namely directed to EGFR, ALK, and KRAS mutated variants [75].

In fact, the targeted therapy of patients with EGFR-mutated tumours is more effective than conventional therapy; and the efficacy of EGFR tyrosine kinase inhibitors (TKIs) is increasing over generations of drugs. First-generation EGFR inhibitors (e.g., gefitinib and erlotinib) have shown increased objective response (ORRs) and progression-free survival (PFS) compared to conventional cytotoxic treatment of patients suffering from EGFR-mutated tumours [73,76]. Second-generation inhibitors, such as afatinib and dacomitinib, are irreversible inhibitors that additionally target the receptors HER2 and HER4 (epidermal growth factor 2 and 4) and were reported to show higher PFS compared to first-generation EGFR inhibitors, such as gefitinib [77].

The fusion between echinoderm microtubule-associated protein-like 4 (EML4) gene and ALK (EML4-ALK) was the first fusion oncogene detected in lung cancer [78]. Fusion genes, involving ALK, are usually mutually exclusive with other oncogenic drivers such as EGFR and KRAS [79]. Crizotinib, a first-generation competitive ATP inhibitor of ALK tyrosine kinases with activity against ALK-fusion-positive NSCLC [80], is associated with higher ORRs and PFS in comparison to cytotoxic therapy in both conventionally treated and untreated patients [81]. In preclinical studies, ceritinib, a second-generation ALK inhibitor, has shown greater antitumour activity than first-generation inhibitors, as crizotinib [82]. Another fusion oncogene, encoding a constitutively activated tyrosine kinase, can result from fusion of ROS1 tyrosine kinase domain with CD74 [83]. Because it has a high homology with the kinase domain of ALK, ALK specific inhibitors, including crizotinib [84] and ceritinib [82], revealed marked activity in ROS1-positive tumours [85]. The same efficacy has 
been observed for crizotinib in NSCLC patients with tumours baring MET tyrosine kinase receptor amplifications [86,87].

Regarding KRAS oncogene, despite the fact that KRAS-MAPK pathway is downstream of EGFR signalling, KRAS-mutation-driven lung cancers, which are mostly adenocarcinomas, do not respond to EGFR TKIs [88] because the mutations in KRAS activate and release mutant KRAS from the upstream regulation. KRAS is the most frequently mutated oncogene in NSCLC patients, but effective therapies targeting mutant KRAS have yet to be developed. However, different therapies directed to KRAS downstream targets, such as MEK (MAPK/ERK kinase), are currently being tested. In a phase III study, NSCLC patients with KRAS mutated tumours treated with MEK inhibitor selumetinib plus docetaxel (taxane) did not show improved PFS compared to taxanes monotherapy [89]. Another MEK inhibitor, trametinib, was also evaluated alone or in combination with taxanes and revealed that combination with chemotherapy increased tolerability and clinical activity in both KRAS-mutant and KRAS-WT NSCLC patients [90].

Antiangiogenic therapy has also been tested in lung cancer patients. Bevacizumab, a monoclonal antibody against vascular endothelial growth factor (VEGF), in combination with paclitaxel (taxane) or carboplatin, significantly improved the median overall survival (OS) and PFS of NSCLC patients with tumours of nonsquamous cell histology [91].

Recently, immunotherapy has emerged as a potential treatment option against lung cancer, taking advantage of the native antitumour immune response [92]. Immune checkpoint blocker (ICB), generated upon T-cell activation, such as monoclonal antibodies that target cytotoxic T-lymphocyte antigen-4 (CTLA-4) and antibodies against PD-1 or PD-L1, are currently the most relevant targets for immunotherapy [73]. During tumorigenesis, PD-1 signalling inactivates T cells that recognize tumour-specific antigens, permitting tumour progression and metastasis [93]. ICBs, currently used or in development for NSCLC treatment, include the anti-PD-1 antibodies nivolumab (human IgG4) and pembrolizumab (humanized IgG4), along with the anti-PD-L1 antibodies atezolizumab (human IgG1, with the Fc domain engineered to prevent antibody-directed cell cytotoxicity), durvalumab (human IgG1 engineered), and avelumab (human IgG1 showing preclinical antibody-directed cell cytotoxicity activity) [74]. ICBs have been mostly used in patients with advanced NSCLC, whose tumours progress upon first-line cytotoxic therapy. Nivolumab treatment was associated with significantly longer median OS compared to treatment with docetaxel in patients with metastatic NSCLC, who had disease progression during or after platinum-based therapy [94,95]. The combination of anti-PD-(L)1 and anti-CTLA-4 monoclonal antibodies can result in higher and longer responses in NSCLC, as observed in experimental models and clinical studies $[96,97]$. Most patients, who achieve an initial benefit from an ICB eventually develop resistance, thus, the challenge is to develop rational combinations that will increase responses or delay the onset of resistance [98].

More recently, multiple trials have been investigating combinations of antiangiogenic agents and immunotherapy in NSCLC [99]. In particular, a clinical trial studied the efficiency of bevacizumab plus nivolumab in III/IV NSCLC patients and it was observed that the combinatory treatment improved PFS and decreased associated toxicity [100].

\subsection{Mechanisms of Resistance to Conventional Therapy}

Cancer chemotherapy resistance is one of the major dilemmas in cancer therapy, resulting in therapeutic failure and increased mortality. NSCLC cells are intrinsically resistant to various anticancer drugs, while SCLC cells can acquire resistance upon cyclic administration of a drug [101]. To address this issue, research has been focusing on how cancer cells modulate their genomes and metabolism to prevent drug influx, to facilitate efflux drugs, to inactivate drugs and/or to repair drug-induced damage [102]. More specifically, mechanisms of drug resistance identified so far include augmented drug eflux, drug inactivation and/or sequestration by enzymes, DNA repair, target modifications and apoptosis defects $[101,103,104]$. Ineffective drug delivery to the tumour, increased metabolism, lack of drug specificity to the tumour and tumour vasculature are additional contributing factors $[105,106]$. 
Additionally, patients treated with chemotherapy develop cumulative genetic mutations which may result in either activation of proto-oncogenes or inactivation of tumour-suppressor genes [101].

\subsubsection{Drug Transporters Increase the Efflux of Chemotherapeutic Drugs}

The overexpression of ATP-binding cassette (ABC) membrane transporters leads to enhanced cytotoxic drug efflux and diminished intracellular accumulation, granting resistance to drugs such as cisplatin, methotrexate, taxanes, anthracyclines, and vinca alkaloids [101,107]. P-glycoprotein (P-gp) is codified by the multidrug-resistance (MDR-1) gene, belongs to the ABC superfamily and functions as an energy-dependent efflux pump of metabolites [108]. Studies have shown an increased expression of P-gp in lung tumours, with notably higher rates in NSCLCs than in SCLCs [101]. In addition, major vault protein (MVP), also known as the lung resistance-related protein (LRP), has been pointed out to be involved in lung cancer drug resistance [109].

3.1.2. Drug Inactivation by Sulphur-Containing Molecules and Role of Antioxidants as a Cause of Drug Resistance

Another mechanism of resistance is by conjugation of the drug with sulphur-containing macromolecules such as metallothioneins (MTs) and GSH [101,110]. MTs are intracellular proteins rich in cysteine content $(30 \%)$ that bind to cytotoxic agents such as platinum compounds and alkylating agents [111]. High MTs levels have been observed in tumour cells with acquired resistance to alkylating agents [110,112]. Moreover, augmented expression of MTs was described in NSCLC with squamous cell lung carcinoma and adenocarcinoma histotypes, but it was not demonstrated in SCLC [113]. Studies also show that MTs play a relevant role in the cellular protection against oxidative stress [114]. A strong correlation between MTs expression and cisplatin and doxorubicin resistance was observed in different cell lines of SCLC $[115,116]$. The GSH S-transferases (GSTs) protect cancer cells from reactive endogenous and exogenous electrophiles, such as prostaglandins, aromatic hydrocarbons and chemotherapeutic agents, through the conjugation with GSH (the most abundant cellular thiol), and scavenges them [101,110,117]. In tumour cells, expression levels of GSTs are increased in comparison to normal cells which may contribute to elevated detoxification of anticancer drugs [118,119]. GST isoenzymes have been reported in lung tumours in higher levels than in normal bronchioles and alveoli [120,121].

More than one mechanism of resistance can act on the same cancer cell/tumour. GS-conjugates are transported out of the cells by efflux transporters, such as multidrug resistance protein 1 (MRP1) and P-gp, thus conferring increased levels of resistance to the cytotoxicity of antineoplastic drugs [122,123]. Multiple studies involving NSCLC and SCLC cell lines suggested that high levels of GSH were associated with decreased platinum-DNA binding and intracellular platinum accumulation, increasing cisplatin resistance [124-126]. Conversely, factors inducing the reduction of cellular GSH content sensitise cancer cells to cisplatin [127]. Nuclear factor erythroid-like 2 (NRF2), a regulator of redox homeostasis upon oxidative stress, is activated by cells in order to upregulate gene networks involved in cytoprotective activities [128]. This transcription factor has been shown to be upregulated in various types of cancer, including skin, breast, prostate, lung and pancreas [129] and has also been associated with chemoresistance [130]. xCT, a downstream target gene of NRF2, responsible for the import of cysteine to support GSH synthesis has been implicated in multidrug resistance of lung cancer [131]. In particular, the $\mathrm{x}_{\mathrm{c}}{ }^{-}$amino acid transport system maintained intracellular GSH and consequently resulted in cisplatin resistance in ovarian cancer cells [132].

Furthermore, cancer cells may develop resistance by overexpressing antioxidants, which protect cells from chemotherapy-induced oxidative stress and cell death, consequently a new redox balance with higher ROS levels is established, a process called "redox resetting" [101,133]. Epirubicin is known to cause oxidative stress by the generation of superoxide and hydrogen peroxide $\left(\mathrm{H}_{2} \mathrm{O}_{2}\right)$ moieties, which drive cancer cell death [134]. Nevertheless, overexpression of antioxidants (e.g., SOD or GSH) neutralizes the oxidative stress leading to drug resistance. Accordingly, high levels of manganese SOD 
(MnSOD) seems to protect lung epithelial cells against oxidative injury [135]. Moreover, malignant mesothelioma cells were reported to have higher levels of SOD mRNA and activities compared with nonmalignant mesothelial cells, but also had elevated catalase and GSH levels, being more resistant to $\mathrm{H}_{2} \mathrm{O}_{2}$ and epirubicin [136]. Accordingly, platinum drugs that generate very high ROS levels can be inactivated by GSH [137].

Alterations in drug metabolism are also associated to resistance since they can lead to drug inactivation or deficient drug activation. Antioxidant systems are able to directly inhibit the antitumour activity of several anticancer agents, such as paclitaxel [138], bortezomib [139] and radiation therapy [140]. Buthionine sulphoximine (BSO) significantly increases paclitaxel cytotoxicity through ROS accumulation [138]. The cellular redox state is associated with enzymatic expression required for the conversion of antimetabolites including 5-fluorouracil (5-FU) and methotrexate to their most active forms $[133,141]$. Capecitabine is an anticancer agent that is converted into 5-FU by thymidine phosphorylase [142], which is encoded by the TYMP gene that can be inactivated by DNA methylation causing capecitabine resistance [143]. These epigenetic alterations can be induced by $\mathrm{H}_{2} \mathrm{O}_{2}$ as DNA methyltransferase 1 (DNMT1) binds more strongly to chromatin after $\mathrm{H}_{2} \mathrm{O}_{2}$ exposure altering the methylation status of CpG regions [144]. The inactivation by UDP glucuronosyl transferase 1 (UGT1A1) by the topoisomerase inhibitor, irinotecan, is induced by the redox-sensing NRF2-KEAP1 pathway [145]. On another hand, the expression of UGT1A1 is decreased by promoter DNA methylation, promoting irinotecan activity [146].

\subsubsection{DNA-Repair Pathways Inducing Resistance to Chemotherapy}

As DNA damage is the main objective of most chemotherapeutic agents, increased capacity of DNA damage repair is one possible mechanism of resistance to the cytotoxic effects of anticancer drugs. Cisplatin for instance induces apoptosis by forming DNA-platinum adducts and by generating ROS, which causes oxidative DNA damage [147]. The nucleotide excision-repair (NER) pathway is one DNA repair pathway involved in the acquisition of platinum-based drug resistance $[101,148]$. Excision-repair cross-complementation group 1 (ERCC1) protein is a molecular indicator of resistance to platinum salts and forms the molecular complex of the NER pathway along with other proteins that are able to correct nucleotides modified by DNA-platinum adducts [149]. An association was found in in vitro studies between the expression of ERCC1 mRNA in NSCLC and resistance to platinum drugs, showing that a low expression of ERCC1 correlated with prolonged survival of NSCLC patients, who were treated with cisplatin plus gemcitabine [150,151]. Mismatch-repair (MMR) pathway repairs base-base and insertion-deletion mismatches during DNA replication [152]. This pathway can repair DNA-platinum adducts, which often results in mitotic stress and cell death [153]. However, this repair pathway is not considered relevant as a mechanism of chemotherapy resistance in lung cancer [101]. In contrast, base-excision-repair (BER) pathway was correlated with chemoresistance, proved by the fact that N-methylpurine DNA Glycosylase (MPG) and Apurinic/Apyrimidinic Endonuclease (APE) inhibition or elimination lead to increased resistance to alkylating agents, such as platinum-based drugs [154].

\subsubsection{Loss of Intracellular Commands of Cell Death as a Cause of Drug Resistance}

Cell death inhibition is another way of contributing to drug resistance. Failure of the intracellular death signalling pathways lead to the alteration of various apoptotic and antiapoptotic intracellular proteins, including Bcl-2, Bax and SAPK/JNK in several types of cancer [101,155]. Indeed, in vitro and in vivo evidence have shown that overexpression of Bcl-2 in SCLC contributes to apoptosis resistance [156]. Cancer cells with defective caspases are resistant to drugs, whose main mechanism of action is the induction of apoptosis. In this sense, NSCLC cells showing low expression of caspases 3 and 9 are resistant to cisplatin chemotherapy [157]. Alterations in antiapoptotic proteins such as IAP (inhibitor of apoptosis protein), particularly XIAP (X-linked inhibitor of apoptosis protein), and survivin have been observed in NSCLC patients with implications in resistance. It was shown that 
XIAP was overexpressed in human H460 NSCLC cell line, leading to the inhibition of the apoptosome formation, pivotal in caspase-dependent cell death [158]. Low expression of survivin in patients was associated with a significantly better OS in comparison to patients with tumours displaying high expression of this protein [159].

Drugs inducing cell death by affecting microtubule stability, such as paclitaxel, kill cells in a Fas/Fas ligand (FasL)-dependent manner [160]. Blockade of Fas/FasL and inhibition of FasL expression by Bcl-2 overexpression are resistance mechanisms to paclitaxel [160]. Conversely, phosphorylation of Bcl-2 induces the expression of FasL, mediated by the nuclear action of NFAT (nuclear factor of activated $\mathrm{T}$ lymphocytes), which is responsive to microtubule damage, thereby restoring paclitaxel sensitivity [161].

\subsection{Mechanisms of Resistance to Targeted Therapy}

Although targeted therapies are revolutionizing the treatment of advanced NSCLC, resistance appears in most patients sooner or later [162]. In this section, we review the mechanisms of resistance that have been discovered in the past few years, in particular to TKIs directed to EGFR, ALK and ROS1, and later we will discuss strategies to overcome drug resistance. The first-generation erlotinib and gefitinib, and second-generation afatinib are now recognized as the standard first-line therapy in NSCLC patients with activating EGFR mutations $[76,163,164]$. However, some patients do not respond to EGFR-TKIs (intrinsic resistance). The most common mechanism for the acquired resistance to EGFR-TKIs is the development of the T790M second mutation within the EGFR kinase domain, which contributes for $50 \%$ of all acquired resistance [165]. The methionine 790 sterically blocks its interaction with TKIs, increasing affinity for ATP and reducing binding of the inhibitor to the kinase domain of EGFR, while keeping the catalytic activity [166]. The MET gene amplification is another frequent mechanism of acquired resistance and affects 5-20\% EGFR-TKI treated NSCLC patients, irrespective of the T790M mutation status [167-169]. Although HER2 amplification is a rare event in lung adenocarcinoma, it accounts for about $1-2 \%$ of total cases and up to $13 \%$ of NSCLC with acquired resistance to EGFR-TKIs [170,171]. Mutated EGFR heterodimerizes with HER2 resulting in heterodimers resistant to degradation [171], supporting EGFR-TKIs resistance in presence of both T790M mutation and HER2 amplification itself as an acquired mechanism of drug exhaustion. KRAS and EGFR mutations are usually mutually exclusive but when they coexist, mainly in tumours under EGFR-TKIs treatment, KRAS mutations can confer resistance to EGFR inhibitors [172]. A study including 60 lung adenocarcinomas, either refractory or sensitive to both gefitinib and erlotinib, indicated that KRAS mutations lead to a lack of sensitivity to these drugs [172].

Another important pathway that has been associated to resistance to EGFR therapy is the PTEN-PI3K-AKT pathway. Phosphatase and tensin homolog (PTEN) acts as a tumour suppressor gene that can decrease tumour growth by inhibiting Akt [173], which can promote cell survival by inactivating several apoptosis mediators, such as Bad and caspases-9. Thus, loss of PTEN leads to increased tumours, since PTEN regulates negatively the PI3K-AKT pathway [174]. In EGFR mutant lung cancer, loss of PTEN led to resistance to EGFR inhibitors such as erlotinib [175], because PI3K activation can somehow interconnect PI3K-AKT and MAPK pathways.

Loss of E-cadherin expression and upregulation of mesenchymal proteins, including vimentin, fibronectin and N-cadherin, are the main characteristic of epithelial-mesenchymal transition (EMT). AXL (AXL receptor tyrosine kinase) is associated with EMT in several tumours and its upregulation in the Hedgehog pathway has been recognized as a mechanism of resistance to targeted drugs in EGFR-mutated NSCLC [176]. In a recent study, gefitinib-mediated ROS promoted EMT and mitochondrial dysfunction concomitant with resistance of lung cancer cells [177]. Moreover, gefitinib treatment in the presence of ROS scavenger provided a partial rescue of mitochondrial aberrations, suggesting that antioxidants may alleviate ROS-mediated resistance.

The evolution of a same tumour from adenocarcinoma to squamous cell carcinoma along the administration of anti-EGFR drugs is a mechanism of acquired drug resistance [178]. However, 
the cause of resistance to anti-EGFR targeted therapy in 18-30\% of NSCLC patients still remains unknown $[167,170]$. The occurrence of tertiary EGFR mutations has been frequently reported in cases with acquired resistance to third-generation TKIs, being demonstrated in in vitro models [179]. Resistance to osimertinib is mainly caused by the EGFR p.Cys797Ser (C797S) mutation in exon 20, consisting of a substitution of a cysteine to a serine in the tyrosine kinase domain, decreases the action of third-generation TKIs, since it reduces their covalent binding to EGFR [180]. The presence of triple mutants (sensitizing mutation, T790M and C797S) supports the resistance to all three generations of EGFR TKIs [181].

NSCLC cells resistant to EGFR TKIs, gefitinib and erlotinib, were shown to exhibit elevated OXPHOS accompanied by elevated glycolysis and activity in TCA cycle [182]. In A549 NSCLC cell line, erlotinib drove ROS-mediated apoptosis via activation of the c-Jun N-terminal kinase (JNK) pathway, leading ultimately to EGFR inhibition [183]. Administration of the ROS scavenger N-acetyl cysteine reversed this phenomenon [184].

Tumours driven by either ALK or ROS1 involving fusion genes exhibit similar mechanisms of resistance to targeted agents. It is well acknowledged in $A L K$ mutated lung cancer the occurrence of mutations in the tyrosine kinase domain, for example L1196M and C1156Y, upon treatment with crizotinib [185]. The L1196 and G1269A substitutions are among the most frequently reported single-nucleotide mutations causing crizotinib resistance in NSCLC [186]. The existence of $A L K$ or ROS1 rearrangements together with KRAS mutations in NSCLC may explain primary or acquired resistance to crizotinib [187,188]. Accordingly, KRAS and NRAS activation through mutations promotes the exhaustion of first-generation inhibitors activity in ROS-1 positive cellular models [189]. Relatively to patients treated with second-generation TKIs, the most common ALK resistance mutation is G1202R, which is associated with in vitro resistance to all currently available ALK inhibitors excluding lorlatinib, a third-generation ALK inhibitor that shows great efficacy in patients with ALK resistance mutations [190], which are more common after treatment with second-generation ALK inhibitors. After ceritinib and alectinib treatment, missense mutations were observed in more than $50 \%$ of the samples, compared with the $30 \%$ of target alterations responsible for crizotinib exhaustion [186]. Despite the efficacy of crizotinib is thought to be specific to ALK inhibition, crizotinib also acts via the generation of superoxide and induction of apoptosis [191].

Resistance against angiogenesis inhibitor bevacizumab was also reported [192]. VEGF binds not only to its tyrosine kinase receptors (VEGFR), which can also interact to Neuropilin-1 (NP1) and Neuropilin-2 (NP2) [193]. Co-expression of NP1 and NP2 in NSCLC tissues is significantly correlated with tumour progression and bad prognosis [194]. Given that bevacizumab blocks VEGF-A, NP1 and NP2 under other stimuli may still increase the effects of VEGFR-1 and VEGFR-2, promoting angiogenesis and activating alternative pathways.

\section{Metabolic Remodelling in Lung Cancer in Response to Oxidative/Alkylating Treatment}

As mentioned above, cisplatin interacts with reducing equivalents, such as GSH and DNA, accounting for increased ROS and DNA damage, which leads to apoptosis [195]. Different studies suggest that metabolic remodelling, in cisplatin-resistant lung cancer cells, involved redox buffering to abrogate cisplatin effect [196-199]. Those lung cancer cells display higher levels of ROS, in part related to the low levels of intracellular thioredoxin [198], but also due to the high levels of GSH and GCL-C (glutamate cysteine ligase catalytic subunit), the first enzyme acting on the synthesis of GSH [195], possibly to counteract the high ROS levels induced by cisplatin [200]. Several studies showed that cisplatin-resistant cells are vulnerable to rapidly ROS-inducing agents. Indeed, a study reported that cisplatin-resistant lung cancer cells were more sensitive to elesclomol, an agent known to exponentially augment ROS [197] inside the cell in such a fast way that cancer cells do not have means of adapting. The xCT cyst(e)ine/glutamate pump, which supplies cells with cysteine essential for GSH production, is upregulated in cisplatin-resistant cells, as they are more sensitive to the $\mathrm{xCT}$ inhibitor riluzole as compared to their parental nonresistant cells [197]. Additionally, cisplatin-resistant 
lung cancer cells have lower rates of glycolysis and rather rely on OXPHOS [201]. Lower levels of hexokinase 1 (HK1) and 2 (HK2), the enzymes that catalyse the first step of glycolysis [202], were also observed in these lung cancer cells, in agreement with the fact that cisplatin exposure decreases HK expression [201,203]. Cisplatin-resistant lung cancer cells also showed decreased levels of glycolysis and lactate production in comparison to the sensitive parental cell lines [197] indicating a lower glycolytic activity or an increased OXPHOS. Under normal growth conditions, cisplatin-resistant lung cancer cells are not sensitive to glucose starvation, however, under hypoxic conditions, these cells are more vulnerable for 2-deoxyglucose (2-DG) treatment, a competitive inhibitor of HK, as compared to the parental cells [196]. Since cells depend on glycolysis for their energy production in the absence of oxygen, the reduced levels of HK in cisplatin-resistant cells probably makes them more vulnerable for 2-DG [201]. Greater rates of OXPHOS and mitochondrial activity, as well as a higher dependence on glutamine are observed in cisplatin-resistant lung cancer cells to compensate the lower glycolytic activity $[197,198,201]$. Furthermore, to fuel the TCA-cycle, $\beta$-oxidation of fatty acids has been reported in cisplatin-resistant lung cancer cells [201]. A recent study showed that cisplatin-resistant lung adenocarcinoma cells have higher MMP and intracellular ATP levels than the nonresistant cells, which also confer them increased aggressiveness [204].

\section{New Therapies, a Comprehensive Adjustment of Therapy to the Metabolic Remodelling}

Anticancer drug resistance is often linked to metabolic alterations and these may be targeted to overcome this issue (Figure 2). Riluzole, a FDA-approved drug for the treatment of amyotrophic lateral sclerosis [205], interferes with glutamate flux and blocks metabotropic glutamate receptors (GRM) signalling. This drug blocked proliferation of melanoma cells expressing GRM in vitro, in vivo and in a phase-0 trial, making riluzole a promising drug to treat melanoma [206,207]. In cisplatin-resistant lung cancer cells, treatment of riluzole disrupted the oxidative defense by significantly reducing glutamate release which, in turn, suppressed GSH levels, resulting in higher ROS accumulation. Riluzole treatment increased ROS by suppressing lactate dehydrogenase A (LDHA) and NAD ${ }^{+}$levels and blocked the cystine/glutamate pump, leading to cell death in cisplatin-resistant cells [197]. Therefore, using riluzole as an antitumour agent against cisplatin resistance in lung cancer should be further explored.

The sugar analogue 2-DG has been shown to be selectively cytotoxic to several tumour cell lines when cultured under anaerobic and/or hypoxic conditions $[208,209]$ and to reduce resistance to cisplatin in an in vivo xenograft model of lung cancer [201]. Another clinical trial reported that 2-DG in combination with docetaxel was well tolerated [213]. Under hypoxia, 2-DG and 2-fluorodeoxyglucose (2-FDG) treatment inhibited glycolysis, and thus lactate production, and also induced higher cell death in cisplatin-resistant cells with low levels of HK2, as compared to their respective parental cells [201]. Hence, targeting metabolic pathways using glycolytic inhibitors, such as 2-FDG or 2-DG, to kill cisplatin-resistant lung cancer cells under anaerobic/hypoxic conditions can be an interesting therapeutic approach.

The ability to repair cisplatin-DNA adducts appears to be involved in the development of cisplatin resistance. The nucleotide excision-repair (NER) pathway and the ERCC1 gene have been pointed out as attractive molecular targets to increase the cytotoxic effects of platinum compounds and overcome their resistance [214]. Metformin has been used for more than 50 years for the treatment of type 2 diabetes mellitus [215] and several studies showed that it has anticancer properties, improving the prognosis of patients with multiple cancers and decreasing the risk of cancer development [216,217]. A study demonstrated that metformin enhanced the sensitivity to a combined treatment of cisplatin and ionizing radiation in in vitro NSCLC models, with a greater effect in cells that are less sensitive to cisplatin [212]. These authors also showed a significant reduction in the expression of ERCC1 after metformin treatment, pointing a possible involvement of the NER pathway in the radio-enhancement effect of the combined cisplatin and metformin treatment. Moreover, metformin was found to reverse resistance to TKIs and ALK inhibitors in lung cancer [211]. Another study using metformin showed that it increased the sensitivity of carboplatin-resistant NSCLC cells to carboplatin treatment in in vitro 
and in vivo models [210]. Metformin treatment decreased the expression of pyruvate kinase muscle isozyme M2 (PKM2), the enzyme that catalyses the final step in glycolysis, and consequently inhibited partially glucose metabolism and reduced ATP levels in carboplatin-resistant NSCLC cells [210].

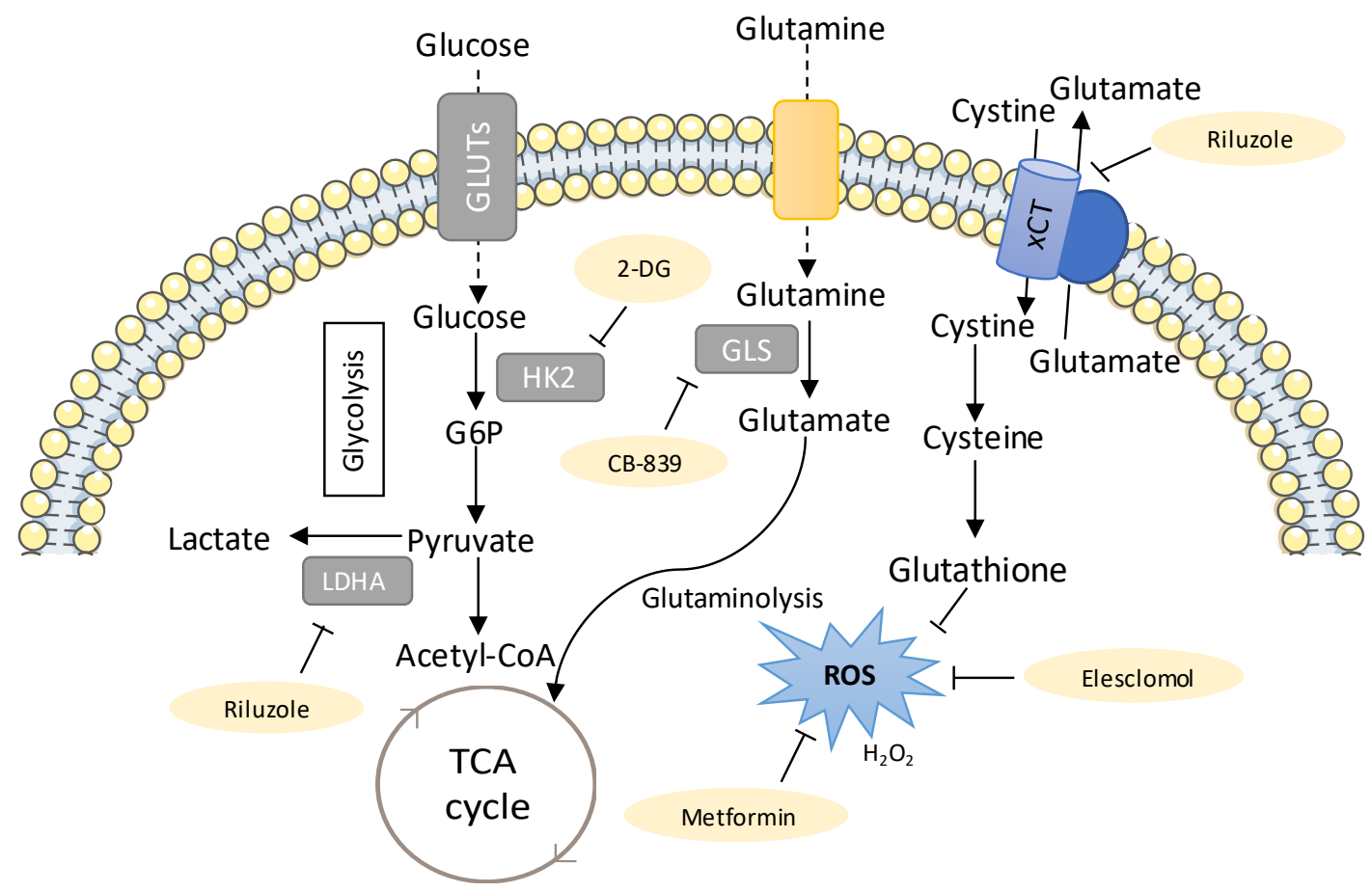

Figure 2. New metabolic therapies targeting drug-resistant lung cancer. The metabolic inhibitors that can be used to target drug-resistant cancers are shown in yellow. The sugar analogue 2-deoxyglucose (2-DG, competitive inhibitor of Hexokinase (HK), has been shown to be selectively cytotoxic to several tumour cell lines under anaerobic and/or hypoxic conditions $[208,209]$ and to reduce resistance to cisplatin in lung cancer cells and an in vivo xenograft model of lung cancer [201]. Thus, 2-DG has the potential of being used clinically as an adjuvant to the classical chemotherapeutic compounds, such as cisplatin. Riluzole interferes with glutamate flux and was shown to increase reactive oxygen species (ROS) by suppressing lactate dehydrogenase A (LDHA) and NAD+ [197]. Glutamate stimulates the glutamine import and glutaminolysis, sustaining the import of cyst(e)ine, which has been related to increased therapy resistance in different cancer models [51], mostly due to its role in glutathione synthesis [52,54]. Riluzole interferes with system xCT-cystine/glutamate antiporter, resulting in decreased GSH levels [197]. Thus, using riluzole as an antitumour agent against cisplatin resistance in lung cancer patients could be further explored. Treatment with CB-389, a glutaminase inhibitor generated a metabolic crisis in EGFR mutant NSCLC cells, resulting in cell death and in rapid tumour regression in mouse NSCLC xenografts [64]. Metformin, an antidiabetic drug, was observed to increase the sensitivity of carboplatin-resistant NSCLC cells to carboplatin treatment in vitro and in vivo [210] and also reversed resistance to tyrosine kinase inhibitors (TKIs) and ALK inhibitors in lung cancer [211]. Another study demonstrated that metformin enhanced the sensitivity to a combined treatment of cisplatin and ionizing radiation in H460 and A549 NSCLC cell lines, with a greater effect in the A549 cell line, which is less sensitized by cisplatin [212]. Elesclomol is another potential therapeutic agent, since it further increased ROS in cisplatin-resistant cells, pushing them beyond their tolerance limit, which ultimately leads to cell death [199].

Tumour cells have the ability to adapt their metabolism to different environments and stressful conditions, increasing adaptability and tumour response to therapies [13,15]. The control of the mitochondrial biogenesis can be a mean of adaption, which is preferentially regulated by the peroxisome proliferator-activated receptor gamma (PPAR- $\gamma$ ) transcriptional coactivator-1 alpha (PGC-1 $\alpha)$ [218]. During the OXPHOS process, protons are pumped into the mitochondrial inner membrane potential 
(MIMP), which is finally dissipated through Complex V, generating ATP [219]. In a study using cisplatin-resistant NSCLC cells, two out of three cell lines showed stable changes towards an augmented OXPHOS function and decreased glycolysis [220]. However, the three cell lines responded in a similar way increasing ROS, MIMP and mitochondrial mass as an early response to cisplatin treatment. The authors also observed a decrease in AIF (proapoptosis) and an increase in Bcl2 (anti-apoptosis), indicating that this mechanism does not replace other classical mechanisms of cisplatin resistance [220]. A stable increase of PGC- $1 \alpha$, is seen in cells with increased OXPHOS activity. Treatment with the mitochondrial inhibitors metformin or rotenone (inhibitors of the complex I of the OXPHOS system) reduces the viability of the cell lines proportionally to their OXPHOS requirements [220]. This study provides new insights into cisplatin resistance mechanism in NSCLC cells which may lead to the design of new therapeutic approaches targeting mitochondria.

In NSCLC, Yuan et al., suggested that PKM2 knockdown could serve as a chemosensitizer to docetaxel, leading to the inhibition of cell viability, cell cycle arrest at G2/M phase and apoptosis [221]. These results further suggest that application of targeting the PKM2 has the potential to be a therapeutic strategy for NSCLC and provides one possible way to improve the chemotherapy effect of docetaxel. The use of NRF2-targeting agents to overcome this chemoresistance has been studied extensively. Stable knockdown of either NRF2 or KEAP1 in NSCLC cells resulted in sensitization to chemotherapeutic drugs. In particular, silencing of KEAPI augmented the expression of PPAR $\gamma$ and genes associated with differentiation [222]. Another study using a mouse model of mutant KrasG12D-induced lung cancer showed that suppressing the NRF2 pathway with the chemical inhibitor brusatol enhanced the antitumour efficacy of cisplatin and reduced the tumour burden as well as improving survival [223].

Although long-term gefitinib treatment can provide effective action against its primary target (aberrant EGFR activity), secondary effects result in high generation of ROS [177]. In a study using lung adenocarcinoma cells, gefitinib treatment, in the presence of a ROS scavenger, provided a partial rescue of mitochondrial aberrations. In addition, the withdrawal of gefitinib from a priori resistant clones correlated with normalized expression of EMT genes. These findings suggest that antioxidants potentially provide therapeutic benefits by attenuating TKI-induced ROS and EMT [177].

In a recent study by Apicella et al., lactate metabolism was found to be involved in the resistance to MET and EGFR TKIs (JNJ-605, crizotinib and erlotinib, respectively), in which patient-derived NSCLC showed upregulated glycolytic metabolism, with high release of lactate [224]. Lactate can act as a signaling molecule which instructs cancer associated fibroblasts (CAFs) to produce hepatocyte growth factor (HGF), whose secretion activates MET signaling in cancer cells, overcoming TKI inhibitory effects [31,224]. The pharmacological inhibition of LDH, MCT4 and MCT1 was sufficient to abrogate the in vivo resistance, making these inhibitors a new therapeutic approach that simultaneously targets lactate metabolism and oncogenes to overcome targeted therapy resistance [224].

\section{Conclusions}

Improved understanding of both cellular metabolism and resistance mechanisms at the molecular level promotes new opportunities to combine chemotherapeutic agents with targeted agents, which may be a promising strategy to overcome chemoresistance and to increase the effectiveness of therapy for lung cancer patients. A concomitant challenge is to find the exact killing profile and adapt it to the metabolic drift in which cancer cells continuously undergo. The course of metabolic adaptation to stressful conditions, such as drug exposure, brings together specialized tumour cell characteristics that are specific to the tumour and the individual. In the future, precision medicine will have to combine metabolic monitoring and evolution data in order to adapt clinical regimens and take advantage of the weaknesses of cancer for therapeutic purposes.

Funding: The research was funded by iNOVA4Health-UID/Multi/04462, a program financially supported by Fundação para a Ciência e Tecnologia/Ministério da Educação e Ciência (FCT-MCTES), through national funds and co-funded by FEDER under the PT2020 Partnership Agreement.

Conflicts of Interest: The authors declare no conflict of interest. 


\section{References}

1. Cairns, R.A.; Mak, T.W. The current state of cancer metabolism. Nat. Rev. Cancer 2016, 16, 613-614. [CrossRef]

2. De Berardinis, R.J.; Chandel, N.S. Fundamentals of cancer metabolism. Sci. Adv. 2016, 2, e1600200. [CrossRef] [PubMed]

3. Warburg, O.; Minami, S. Versuche an Überlebendem Carcinomgewebe. Klin. Wochenschr. 1923, 2, 776-777. [CrossRef]

4. Dang, C.V. Links between metabolism and cancer. Genes. Dev. 2012, 26, 877-890. [CrossRef] [PubMed]

5. Koppenol, W.H.; Bounds, P.L.; Dang, C.V. Otto Warburg's contributions to current concepts of cancer metabolism. Nat. Rev. Cancer 2011, 11, 325-337. [CrossRef]

6. Kroemer, G.; Pouyssegur, J. Tumor Cell Metabolism: Cancer's Achilles' Heel. Cancer Cell 2008, 13, 472-482. [CrossRef]

7. Zheng, J. Energy metabolism of cancer: Glycolysis versus oxidative phosphorylation (review). Oncol. Lett. 2012, 4, 1151-1157. [CrossRef]

8. Gentric, G.; Mieulet, V.; Mechta-Grigoriou, F. Heterogeneity in Cancer Metabolism: New Concepts in an Old Field. Antioxid. Redox Signal 2017, 26, 462-485. [CrossRef]

9. Bost, F.; Decoux-Poullot, A.-G.; Tanti, J.F.; Clavel, S. Energy disruptors: Rising stars in anticancer therapy? Oncogenesis 2016, 5, e188. [CrossRef]

10. Vander Heiden, M.G.; Cantley, L.C.; Thompson, C.B. Understanding the Warburg effect: The metabolic requirements of cell proliferation. Science 2009, 324, 1029-1033. [CrossRef]

11. Pavlova, N.N.; Thompson, C.B. The Emerging Hallmarks of Cancer Metabolism. Cell Metab. 2016, 23, 27-47. [CrossRef] [PubMed]

12. Altman, B.J.; Stine, Z.E.; Dang, C.V. Corrigendum: From Krebs to clinic: Glutamine metabolism to cancer therapy. Nat. Rev. Cancer 2016, 16, 773. [CrossRef] [PubMed]

13. Obre, E.; Rossignol, R. Emerging concepts in bioenergetics and cancer research: Metabolic flexibility, coupling, symbiosis, switch, oxidative tumors, metabolic remodeling, signaling and bioenergetic therapy. Int. J. Biochem. Cell Biol. 2015, 59, 167-181. [CrossRef] [PubMed]

14. Cocetta, V.; Ragazzi, E.; Montopoli, M. Mitochondrial Involvement in Cisplatin Resistance. Int. J. Mol. Sci. 2019, 20, 3384. [CrossRef] [PubMed]

15. Cruz-Bermúdez, A.; Vicente-Blanco, R.J.; Gonzalez-Vioque, E.; Provencio, M.; Fernández-Moreno, M.; Garesse, R. Spotlight on the relevance of mtDNA in cancer. Clin. Transl. Oncol. 2017, 19, 409-418. [CrossRef]

16. Okon, I.S.; Zou, M.H. Mitochondrial ROS and cancer drug resistance: Implications for therapy. Pharmacol. Res. 2015, 100, 170-174. [CrossRef]

17. Che, M.; Wang, R.; Li, X.; Wang, H.Y.; Zheng, X.F.S. Expanding roles of superoxide dismutases in cell regulation and cancer. Drug Discov. Today 2016, 21, 143-149. [CrossRef]

18. Bansal, A.; Celeste Simon, M. Glutathione metabolism in cancer progression and treatment resistance. J. Cell Biol. 2018, 17, 2291-2298. [CrossRef]

19. Gandin, V.; Fernandes, A.P. Metal- and semimetal-containing inhibitors of thioredoxin reductase as anticancer agents. Molecules 2015, 20, 12732-12756. [CrossRef]

20. Torre, L.A.; Siegel, R.L.; Jemal, A. Lung cancer statistics. Adv. Exp. Med. Biol. 2016, 893, 1-19. [CrossRef]

21. Sher, T.; Dy, G.K.; Adjei, A.A. Small cell lung cancer. Mayo Clin. Proc. 2008, 83, 355-367. [CrossRef] [PubMed]

22. Denisenko, T.V.; Budkevich, I.N.; Zhivotovsky, B. Cell death-based treatment of lung adenocarcinoma. Cell Death Dis. 2018, 9, 117. [CrossRef] [PubMed]

23. Sellers, K.; Allen, T.D.; Bousamra, M.; Tan, J.L.; Méndez-Lucas, A.; Lin, W.; Bah, N.; Chernyavskaya, Y.; MacRae, J.I.; Higashi, R.M.; et al. Metabolic reprogramming and Notch activity distinguish between non-small cell lung cancer subtypes. Br. J. Cancer 2019, 121, 51-64. [CrossRef] [PubMed]

24. Hanahan, D.; Weinberg, R.A. Leading Edge Review Hallmarks of Cancer: The Next Generation. Cell 2011, 144, 646-674. [CrossRef] [PubMed]

25. Lopes-Coelho, F.; Gouveia-Fernandes, S.; Nunes, S.C.; Serpa, J. Metabolic Dynamics in Breast Cancer: Cooperation between Cancer and Stromal Breast Cancer Cells. J. Clin. Breast Cancer Res. 2017, 1, 1-7.

26. Reisz, J.A.; D'Alessandro, A. Measurement of metabolic fluxes using stable isotope tracers in whole animals and human patients. Curr. Opin. Clin. Nutr. Metab. Care 2017, 20, 366-374. [CrossRef] 
27. Davidson, S.M.; Papagiannakopoulos, T.; Olenchock, B.A.; Heyman, J.E.; Keibler, M.A.; Luengo, A.; Bauer, M.R.; Jha, A.K.; O’Brien, J.P.; Pierce, K.A.; et al. Environment impacts the metabolic dependencies of ras-driven non-small cell lung cancer. Cell Metab. 2016, 23, 517-528. [CrossRef]

28. Hensley, C.T.; Faubert, B.; Yuan, Q.; Lev-Cohain, N.; Jin, E.; Kim, J.; Jiang, L.; Ko, B.; Skelton, R.; Loudat, L.; et al. Metabolic Heterogeneity in Human Lung Tumors. Cell 2016. [CrossRef]

29. Faubert, B.; Li, K.Y.; Cai, L.; Hensley, C.T.; Kim, J.; Zacharias, L.G.; Yang, C.; Do, Q.N.; Doucette, S.; Burguete, D.; et al. Lactate Metabolism in Human Lung Tumors. Cell 2017. [CrossRef]

30. Fan, T.W.M.; Lane, A.N.; Higashi, R.M.; Farag, M.A.; Gao, H.; Bousamra, M.; Miller, D.M. Altered regulation of metabolic pathways in human lung cancer discerned by $13 \mathrm{C}$ stable isotope-resolved metabolomics (SIRM). Mol. Cancer 2009. [CrossRef]

31. Vander Linden, C.; Corbet, C. Reconciling environment-mediated metabolic heterogeneity with the oncogene-driven cancer paradigm in precision oncology. Semin. Cell. Dev. Biol. 2019. [CrossRef] [PubMed]

32. Buescher, J.M.; Antoniewicz, M.R.; Boros, L.G.; Burgess, S.C.; Brunengraber, H.; Clish, C.B.; DeBerardinis, R.J.; Feron, O.; Frezza, C.; Ghesquiere, B.; et al. A roadmap for interpreting $13 \mathrm{C}$ metabolite labeling patterns from cells. Curr. Opin. Biotechnol. 2015, 34, 189-201. [CrossRef] [PubMed]

33. Sellers, K.; Fox, M.P.; Li, M.B.; Slone, S.P.; Higashi, R.M.; Miller, D.M.; Wang, Y.; Yan, J.; Yuneva, M.O.; Deshpande, R.; et al. Pyruvate carboxylase is critical for non-small-cell lung cancer proliferation. J. Clin. Investig. 2015. [CrossRef] [PubMed]

34. Adekola, K.; Rosen, S.T.; Shanmugam, M. Glucose transporters in cancer metabolism. Curr. Opin. Oncol. 2012, 24, 650-654. [CrossRef]

35. Mathupala, S.P.; Rempel, A.; Pedersen, P.L. Glucose catabolism in cancer cells: Identification and characterization of a marked activation response of the type II hexokinase gene to hypoxic conditions. J. Biol. Chem. 2001, 276, 43407-43412. [CrossRef]

36. Sun, Q.; Chen, X.; Ma, J.; Peng, H.; Wang, F.; Zha, X.; Wang, Y.; Jing, Y.; Yang, H.; Chen, R.; et al. Mammalian target of rapamycin up-regulation of pyruvate kinase isoenzyme type M2 is critical for aerobic glycolysis and tumor growth. Proc. Natl. Acad. Sci. USA 2011, 108, 4129-4134. [CrossRef]

37. Wang, H.; Wang, L.; Zhang, Y.; Wang, J.; Deng, Y.; Lin, D. Inhibition of glycolytic enzyme hexokinase II (HK2) suppresses lung tumor growth. Cancer Cell Int. 2016, 16, 9. [CrossRef]

38. Makinoshima, H.; Takita, M.; Matsumoto, S.; Yagishita, A.; Owada, S.; Esumi, H.; Tsuchihara, K. Epidermal growth factor receptor (EGFR) signaling regulates global metabolic pathways in EGFR-mutated lung adenocarcinoma. J. Biol. Chem. 2014, 289, 20813-20823. [CrossRef]

39. Min, H.Y.; Lee, H.Y. Oncogene-driven metabolic alterations in cancer. Biomol. Ther. 2018, 26, 45-56. [CrossRef]

40. Zhang, J.; Song, F.; Zhao, X.; Jiang, H.; Wu, X.; Wang, B.; Zhou, M.; Tian, M.; Shi, B.; Wang, H.; et al. EGFR modulates monounsaturated fatty acid synthesis through phosphorylation of SCD1 in lung cancer. Mol. Cancer. 2017. [CrossRef]

41. Martín-Bernabé, A.; Cortés, R.; Lehmann, S.G.; Steve, M.; Cascante, M.; Bourgoin-Voillard, S. Quantitative proteomic approach to understand metabolic adaptation in non-small cell lung cancer. J. Proteome. Res. 2014, 13, 4695-4704. [CrossRef] [PubMed]

42. Palsson-McDermott, E.M.; O'Neill, L.A.J. The Warburg effect then and now: From cancer to inflammatory diseases. BioEssays 2013, 35, 965-973. [CrossRef] [PubMed]

43. Choi, H.; Paeng, J.C.; Kim, D.W.; Lee, J.K.; Park, C.M.; Kang, K.W.; Chung, J.K.; Lee, D.S. Metabolic and metastatic characteristics of ALK-rearranged lung adenocarcinoma on FDG PET/CT. Lung Cancer 2013, 79, 242-247. [CrossRef] [PubMed]

44. Halestrap, A.P.; Price, N.T. The proton-linked monocarboxylate transporter (MCT) family: Structure, function and regulation. Biochem. J. 1999, 343, 281-299. [CrossRef] [PubMed]

45. Ke, Q.; Costa, M. Hypoxia-Inducible Factor-1 (HIF-1). Mol. Pharmacol. 2006, 70, 1469-1480. [CrossRef] [PubMed]

46. Papandreou, I.; Cairns, R.A.; Fontana, L.; Lim, A.L.; Denko, N.C. HIF-1 mediates adaptation to hypoxia by actively downregulating mitochondrial oxygen consumption. Cell. Metab. 2006, 3, 187-197. [CrossRef]

47. Hiyama, N.; Ando, T.; Maemura, K.; Sakatani, T.; Amano, Y.; Watanabe, K.; Kage, H.; Yatomi, Y.; Nagase, T.; Nakajima, J.; et al. Glutamate-cysteine ligase catalytic subunit is associated with cisplatin resistance in lung adenocarcinoma. Jpn. J. Clin. Oncol. 2018, 48, 303-307. [CrossRef] 
48. Migita, T.; Narita, T.; Nomura, K.; Miyagi, E.; Inazuka, F.; Matsuura, M.; Ushijima, M.; Mashima, T.; Seimiya, H.; Satoh, Y.; et al. ATP citrate lyase: Activation and therapeutic implications in non-small cell lung cancer. Cancer Res. 2008. [CrossRef]

49. Zhang, W.C.; Ng, S.C.; Yang, H.; Rai, A.; Umashankar, S.; Ma, S.; Soh, B.S.; Sun, L.L.; Tai, B.C.; Nga, M.E.; et al. Glycine decarboxylase activity drives non-small cell lung cancer tumor-initiating cells and tumorigenesis. Cell 2012. [CrossRef]

50. Ji, X.; Qian, J.; Rahman, S.M.J.; Siska, P.J.; Zou, Y.; Harris, B.K.; Hoeksema, M.D.; Trenary, I.A.; Heidi, C.; Eisenberg, R.; et al. xCT (SLC7A11)-mediated metabolic reprogramming promotes non-small cell lung cancer progression. Oncogene 2018, 37, 5007-5019. [CrossRef]

51. Nunes, S.C.; Ramos, C.; Lopes-Coelho, F.; Sequeira, C.O.; Silva, F.; Gouveia-Fernandes, S.; Rodrigues, A.; Guimarães, A.; Silveira, M.; Abreu, S.; et al. Cysteine allows ovarian cancer cells to adapt to hypoxia and to escape from carboplatin cytotoxicity. Sci. Rep. 2018, 8, 9513. [CrossRef] [PubMed]

52. Colla, R.; Izzotti, A.; De Ciucis, C.; Fenoglio, D.; Ravera, S.; Speciale, A.; Ricciarelli, R.; Furfaro, A.L.; Pulliero, A.; Passalacqua, M.; et al. Glutathione-mediated antioxidant response and aerobic metabolism: Two crucial factors involved in determining the multi-drug resistance of high-risk neuroblastoma. Oncotarget 2016, 7, 70715-70737. [CrossRef] [PubMed]

53. Mallappa, S.; Neeli, P.K.; Karnewar, S.; Kotamraju, S. Doxorubicin induces prostate cancer drug resistance by upregulation of ABCG4 through GSH depletion and CREB activation: Relevance of statins in chemosensitization. Mol. Carcinog. 2019. [CrossRef] [PubMed]

54. Nunes, S.C.; Serpa, J. Glutathione in ovarian cancer: A double-edged sword. Int. J. Mol. Sci. 2018, 19, 1882. [CrossRef] [PubMed]

55. Ciamporcero, E.; Daga, M.; Pizzimenti, S.; Roetto, A.; Dianzani, C.; Compagnone, A.; Palmieri, A.; Ullio, C.; Cangemi, L.; Pili, R.; et al. Crosstalk between Nrf2 and YAP contributes to maintaining the antioxidant potential and chemoresistance in bladder cancer. Free Radic. Biol. Med. 2018, 115, 447-457. [CrossRef]

56. Chen, P.-H.; Cai, L.; Kim, H.S.; Britt, R.; Xiao, G.; White, M.A.; Minna, J.D.; DeBerardinis, R.J. Metabolic diversity in human non-small cell lung cancer. Cancer Metab. 2014. [CrossRef]

57. Vaupel, P. Hypoxia and Aggressive Tumor Phenotype: Implications for Therapy and Prognosis. Oncologist 2008, 13, 21-26. [CrossRef]

58. Zhou, J.; Schmid, T.; Schnitzer, S.; Brüne, B. Tumor hypoxia and cancer progression. Cancer Lett. 2006, 237, 10-21. [CrossRef]

59. Rankin, E.B.; Giaccia, A.J. Hypoxic control of metastasis. Science 2016, 352, 175-180. [CrossRef]

60. Giatromanolaki, A.; Koukourakis, M.I.; Sivridis, E.; Turley, H.; Talks, K.; Pezzella, F.; Gatter, K.C.; Harris, A.L. Relation of hypoxia inducible factor $1 \alpha$ and $2 \alpha$ in operable non-small cell lung cancer to angiogenic/molecular profile of tumours and survival. Br. J. Cancer 2001, 85, 881-890. [CrossRef]

61. Karetsi, E.; Ioannou, M.G.; Kerenidi, T.; Minas, M.; Molyvdas, P.A.; Gourgoulianis, K.I.; Paraskeva, E. Differential expression of hypoxia-inducible factor $1 \alpha$ in non-small cell lung cancer and small cell lung cancer. Clinics 2012, 67, 1373-1378. [CrossRef]

62. Pikor, L.A.; Ramnarine, V.R.; Lam, S.; Lam, W.L. Genetic alterations defining NSCLC subtypes and their therapeutic implications. Lung Cancer 2013, 82, 179-189. [CrossRef] [PubMed]

63. Kerr, E.M.; Martins, C.P. Metabolic rewiring in mutant Kras lung cancer. FEBS J. 2018, 285, 28-41. [CrossRef] [PubMed]

64. Momcilovic, M.; Bailey, S.T.; Lee, J.T.; Fishbein, M.C.; Magyar, C.; Braas, D.; Graeber, T.; Jackson, N.; Czernin, J.; Emberley, E.; et al. Targeted Inhibition of EGFR and Glutaminase Induces Metabolic Crisis in EGFR Mutant Lung Cancer. Cell Rep. 2017, 18, 601-610. [CrossRef] [PubMed]

65. Kimmelman, A.C. Metabolic dependencies in RAS-driven cancers. Clin. Cancer Res. 2015, 21, $1828-1834$. [CrossRef] [PubMed]

66. Kawada, K.; Toda, K.; Sakai, Y. Targeting metabolic reprogramming in KRAS-driven cancers. Int. J. Clin. Oncol. 2017, 22, 651-659. [CrossRef]

67. Ying, H.; Kimmelman, A.C.; Lyssiotis, C.A.; Hua, S.; Chu, G.; Fletcher-Sananikone, E.; Locasale, J.W.; Son, J.; Zhang, H.; Coloff, J.L.; et al. Oncogenic kras maintains pancreatic tumors through regulation of anabolic glucose metabolism. Cell 2012, 149, 656-670. [CrossRef] 
68. Son, J.; Lyssiotis, C.A.; Ying, H.; Wang, X.; Hua, S.; Ligorio, M.; Perera, R.M.; Ferrone, C.R.; Mullarky, E.; Shyh-Chang, N.; et al. Glutamine supports pancreatic cancer growth through a KRAS-regulated metabolic pathway. Nature 2013, 496, 101-105. [CrossRef]

69. Onetti, R.; Baulida, J.; Bassols, A. Increased glucose transport in ras-transformed fibroblasts: A possible role for N-glycosylation of GLUT1. FEBS Lett. 1997, 407, 267-270. [CrossRef]

70. Brunelli, L.; Caiola, E.; Marabese, M.; Broggini, M.; Pastorelli, R. Capturing the metabolomic diversity of KRAS mutants in non-small-cell lung cancer cells. Oncotarget 2014. [CrossRef]

71. Kerr, E.M.; Gaude, E.; Turrell, F.K.; Frezza, C.; Martins, C.P. Mutant Kras copy number defines metabolic reprogramming and therapeutic susceptibilities. Nature 2016, 531, 110-113. [CrossRef] [PubMed]

72. Kim, W.Y.; Perera, S.; Zhou, B.; Carretero, J.; Jen, J.Y.; Heathcote, S.A.; Jackson, A.L.; Nikolinakos, P.; Ospina, B.; Naumov, G.; et al. HIF2 $\alpha$ cooperates with RAS to promote lung tumorigenesis in mice. J. Clin. Investig. 2009, 119, 2160-2170. [CrossRef] [PubMed]

73. Herbst, R.S.; Morgensztern, D.; Boshoff, C. The biology and management of non-small cell lung cancer. Nature 2018, 553, 446-454. [CrossRef] [PubMed]

74. Hirsch, F.R.; Scagliotti, G.V.; Mulshine, J.L.; Kwon, R.; Curran, W.J.; Wu, Y.-L.; Paz-Ares, L. Lung cancer: Current therapies and new targeted treatments. Lancet 2017, 389, 299-311. [CrossRef]

75. Pao, W.; Hutchinson, K.E. Chipping away at the lung cancer genome. Nat. Publ. Gr. 2012, 18, 349-351. [CrossRef] [PubMed]

76. Mok, T.S.; Wu, Y.L.; Thongprasert, S.; Yang, C.H.; Chu, D.T.; Saijo, N.; Sunpaweravong, P.; Han, B.; Margono, B.; Ichinose, Y.; et al. Gefitinib or carboplatin-paclitaxel in pulmonary adenocarcinoma. N. Engl. J. Med. 2009. [CrossRef]

77. Paz-Ares, L.; Tan, E.H.; O’Byrne, K.; Zhang, L.; Hirsh, V.; Boyer, M.; Yang, J.C.H.; Mok, T.; Lee, K.H.; Lu, S.; et al. Afatinib versus gefitinib in patients with EGFR mutation-positive advanced non-small-cell lung cancer: Overall survival data from the phase IIb LUX-Lung 7 trial. Ann. Oncol. 2017. [CrossRef]

78. Soda, M.; Choi, Y.L.; Enomoto, M.; Takada, S.; Yamashita, Y.; Ishikawa, S.; Fujiwara, S.I.; Watanabe, H.; Kurashina, K.; Hatanaka, H.; et al. Identification of the transforming EML4-ALK fusion gene in non-small-cell lung cancer. Nature 2007. [CrossRef]

79. Gainor, J.F.; Varghese, A.M.; Ou, S.H.I.; Kabraji, S.; Awad, M.M.; Katayama, R.; Pawlak, A.; Mino-Kenudson, M.; Yeap, B.Y.; Riely, G.J.; et al. ALK rearrangements are mutually exclusive with mutations in EGFR or KRAS: An analysis of 1,683 patients with non-small cell lung cancer. Clin. Cancer Res. 2013, 19, 4273-4281. [CrossRef]

80. Kwak, E.L.; Bang, Y.J.; Camidge, D.R.; Shaw, A.T.; Solomon, B.; Maki, R.G.; Ou, S.H.I.; Dezube, B.J.; Jänne, P.A.; Costa, D.B.; et al. Anaplastic lymphoma kinase inhibition in non-small-cell lung cancer. N. Engl. J. Med. 2010, 28, 1693-1703. [CrossRef]

81. Shaw, A.T.; Kim, D.W.; Nakagawa, K.; Seto, T.; Crinó, L.; Ahn, M.J.; De Pas, T.; Besse, B.; Solomon, B.J.; Blackhall, F.; et al. Crizotinib versus chemotherapy in advanced ALK-positive lung cancer. N. Engl. J. Med. 2013. [CrossRef] [PubMed]

82. Shaw, A.T.; Kim, D.W.; Mehra, R.; Tan, D.S.W.; Felip, E.; Chow, L.Q.M.; Camidge, D.R.; Vansteenkiste, J.; Sharma, S.; De Pas, T.; et al. Ceritinib in ALK-rearranged non-small-cell lung cancer. N. Engl. J. Med. 2014, 370, 1189-1197. [CrossRef] [PubMed]

83. Facchinetti, F.; Rossi, G.; Bria, E.; Soria, J.; Besse, B.; Minari, R.; Friboulet, L.; Tiseo, M. Oncogene addiction in non-small cell lung cancer: Focus on ROS1 inhibition. Cancer Treat. Rev. 2017, 55, 83-95. [CrossRef] [PubMed]

84. Shaw, A.T.; Ou, S.H.I.; Bang, Y.J.; Camidge, D.R.; Solomon, B.J.; Salgia, R.; Riely, G.J.; Varella-Garcia, M.; Shapiro, G.I.; Costa, D.B.; et al. Crizotinib in ROS1-rearranged non-small-cell lung cancer. N. Engl. J. Med. 2014, 371, 1963-1971. [CrossRef]

85. Ye, M.; Zhang, X.; Li, N.; Zhang, Y.; Jing, P.; Chang, N.; Wu, J.; Ren, X.; Zhang, J. ALK and ROS1 as targeted therapy paradigms and clinical implications to overcome crizotinib resistance. Oncotarget 2016, 7, 12289-12304. [CrossRef]

86. Sadiq, A.A.; Salgia, R. MET As a possible target for non-small-cell lung cancer. J. Clin. Oncol. 2013, 31, 1089-1096. [CrossRef] 
87. Camidge, D.R.; Ou, S.-H.I.; Shapiro, G.; Otterson, G.A.; Villaruz, L.C.; Villalona-Calero, M.; Iafrate, A.J.; Varella-Garcia, M.; Dacic, S.; Cardarella, S.; et al. Efficacy and safety of crizotinib in patients with advanced c-MET -amplified non-small cell lung cancer (NSCLC). J. Clin. Oncol. 2014. [CrossRef]

88. Murray, S.; Dahabreh, I.J.; Linardou, H.; Manoloukos, M.; Bafaloukos, D.; Kosmidis, P. Somatic mutations of the tyrosine kinase domain of epidermal growth factor receptor and tyrosine kinase inhibitor response to TKIs in non-small cell lung cancer: An analytical database. J. Thorac. Oncol. 2008. [CrossRef]

89. Yang, H.; Liang, S.-Q.; Schmid, R.A.; Peng, R.-W. New Horizons in KRAS-Mutant Lung Cancer: Dawn After Darkness. Front. Oncol. 2019, 9, 1-13. [CrossRef]

90. Blumenschein, G.R.J.; Smit, E.F.; Planchard, D.; Kim, D.W.; Cadranel, J.; De Pas, T.; Dunphy, F.; Udud, K.; Ahn, M.J.; Hanna, N.H.; et al. A randomized phase 2 study of the MEK1/MEK2 inhibitor trametinib (GSK1120212) compared with docetaxel in. Ann. Oncol. 2015, 26, 894-901. [CrossRef]

91. Sandler, A.; Gray, R.; Perry, M.C.; Brahmer, J.; Schiller, J.H.; Dowlati, A.; Lilenbaum, R.; Johnson, D.H. Paclitaxel-carboplatin alone or with bevacizumab for non-small-cell lung cancer. N. Engl. J. Med. 2006, 355, 2542-2550. [CrossRef] [PubMed]

92. Qin, A.; Coffey, D.G.; Warren, E.H.; Ramnath, N. Mechanisms of immune evasion and current status of checkpoint inhibitors in non-small cell lung cancer. Cancer Med. 2016, 5, 2567-2578. [CrossRef] [PubMed]

93. Iwai, Y.; Ishida, M.; Tanaka, Y.; Okazaki, T.; Honjo, T.; Minato, N. Involvement of PD-L1 on tumor cells in the escape from host immune system and tumor immunotherapy by PD-L1 blockade. Proc. Natl. Acad. Sci. USA 2002. [CrossRef] [PubMed]

94. Brahmer, J.; Reckamp, K.L.; Baas, P.; Crinò, L.; Eberhardt, W.E.E.; Poddubskaya, E.; Antonia, S.; Pluzanski, A.; Vokes, E.E.; Holgado, E.; et al. Nivolumab versus docetaxel in advanced squamous-cell non-small-cell lung cancer. N. Engl. J. Med. 2015, 373, 123-135. [CrossRef] [PubMed]

95. Borghaei, H.; Paz-Ares, L.; Horn, L.; Spigel, D.R.; Steins, M.; Ready, N.E.; Chow, L.Q.; Vokes, E.E.; Felip, E.; Holgado, E.; et al. Nivolumab versus docetaxel in advanced nonsquamous non-small-cell lung cancer. $N$. Engl. J. Med. 2015, 373, 1627-1639. [CrossRef] [PubMed]

96. Curran, M.A.; Montalvo, W.; Yagita, H.; Allison, J.P. PD-1 and CTLA-4 combination blockade expands infiltrating $\mathrm{T}$ cells and reduces regulatory $\mathrm{T}$ and myeloid cells within B16 melanoma tumors. Proc. Natl. Acad. Sci. USA 2010, 107, 4275-4280. [CrossRef]

97. Hellmann, M.D.; Rizvi, N.A.; Goldman, J.W.; Gettinger, S.N.; Borghaei, H.; Brahmer, J.R.; Ready, N.E.; Gerber, D.E.; Chow, L.Q.; Juergens, R.A.; et al. Nivolumab plus ipilimumab as first-line treatment for advanced non-small-cell lung cancer (CheckMate 012): Results of an open-label, phase 1, multicohort study. Lancet. Oncol. 2017, 18, 31-41. [CrossRef]

98. Sharma, P.; Hu-Lieskovan, S.; Wargo, J.A.; Ribas, A. Primary, Adaptive, and Acquired Resistance to Cancer Immunotherapy. Cell 2017, 168, 707-723. [CrossRef]

99. Qu, J.; Zhang, Y.; Chen, X.; Yang, H.; Zhou, C.; Yang, N. Newly developed anti-angiogenic therapy in non-small cell lung cancer. Oncotarget 2018, 9, 10147-10163. [CrossRef]

100. Rizvi, N.A.; Antonia, S.J.; Shepherd, F.A.; Chow, L.Q.; Goldman, J.; Shen, Y.; Chen, A.C.; Gettinger, S. Nivolumab (Anti-PD-1; BMS-936558, ONO-4538) Maintenance as Monotherapy or in Combination With Bevacizumab (BEV) for Non-Small Cell Lung Cancer (NSCLC) Previously Treated With Chemotherapy. Radiat. Oncol. 2014, 90, S32. [CrossRef]

101. Shanker, M.; Willcutts, D.; Roth, J.A.; Ramesh, R. Drug resistance in lung cancer. Lung Cancer Targets Ther. 2010, 1, 23-36. [CrossRef]

102. Alfarouk, K.O.; Stock, C.M.; Taylor, S.; Walsh, M.; Muddathir, A.K.; Verduzco, D.; Bashir, A.H.H.; Mohammed, O.Y.; Elhassan, G.O.; Harguindey, S.; et al. Resistance to cancer chemotherapy: Failure in drug response from ADME to P-gp. Cancer Cell Int. 2015, 15, 71. [CrossRef] [PubMed]

103. Ambudkar, S.V.; Dey, S.; Hrycyna, C.A.; Ramachandra, M.; Pastan, I.; Gottesman, M.M. Biochemical, cellular, and pharmacological aspects of the multidrug transporter. Annu. Rev. Pharmacol. Toxicol. 1999, 39, 361-398. [CrossRef] [PubMed]

104. Eastman, A.; Schulte, N. Enhanced DNA Repair as a Mechanism of Resistance to cis-Diamminedichloroplatinum(II). Biochemistry 1988. [CrossRef]

105. Green, S.K.; Frankel, A.; Kerbel, R.S. Adhesion-dependent multicellular drug resistance. Anticancer. Drug Des. 1999, 14, 153-168. 
106. Morin, P.J. Drug resistance and the microenvironment: Nature and nurture. Drug Resist. Updat. 2003. [CrossRef]

107. Shair, I.; He, W.; Yin, L. Understanding of human ATP binding cassette superfamily and novel multidrug resistance modulators to overcome MDR. Biomed. Pharmacother. 2018, 100, 335-348. [CrossRef]

108. Taylor, J.C.; Horvath, A.R.; Higgins, C.F.; Begley, G.S. The multidrug resistance P-glycoprotein. Oligomeric state and intramolecular interactions. J. Biol. Chem. 2001, 276, 36075-36078. [CrossRef]

109. Scheffer, G.L.; Schroeijers, A.B.; Izquierdo, M.A.; Wiemer, E.A.C.; Scheper, R.J. Lung resistance-related protein/major vault protein and vaults in multidrug-resistant cancer. Curr. Opin. Oncol. 2000, 12, 550-556. [CrossRef]

110. Damia, G.; D'Incalci, M. Mechanisms of resistance to alkylating agents. Cytotechnology 1998, 27, $165-173$. [CrossRef]

111. Thirumoorthy, N.; Manisenthil Kumar, K.T.; Sundar, A.S.; Panayappan, L.; Chatterjee, M. Metallothionein: An overview. World J. Gastroenterol. 2007, 21, 993-996. [CrossRef] [PubMed]

112. Kelley, S.L.; Basu, A.; Teicher, B.A.; Hacker, M.P.; Hamer, D.H.; Lazo, J.S. Overexpression of metallothionein confers resistance to anticancer drugs. Science 1988, 30, 1813-1815. [CrossRef] [PubMed]

113. Theocharis, S.; Karkantaris, C.; Philipides, T.; Agapitos, E.; Gika, A.; Margeli, A.; Kittas, C.; Koutselinis, A. Expression of metallothionein in lung carcinoma: Correlation with histological type and grade. Histopathology 2002, 40, 143-151. [CrossRef]

114. Yang, M.; Chitambar, C.R. Role of oxidative stress in the induction of metallothionein-2A and heme oxygenase-1 gene expression by the antineoplastic agent gallium nitrate in human lymphoma cells. Free Radic. Biol. Med. 2008, 45, 763-772. [CrossRef] [PubMed]

115. Vandier, D.; Calvez, V.; Massade, L.; Gouyette, A.; Mickley, L.; Fojo, T.; Rixe, O. Transactivation of the metallothionein promoter in cisplatin-resistant cancer cells: A specific gene therapy strategy. J. Natl. Cancer Inst. 2000, 92, 642-647. [CrossRef] [PubMed]

116. Hao, X.Y.; Bergh, J.; Brodin, O.; Heltman, U.; Mannervik, B. Acquired resistance to cisplatin and doxorubicin in a small cell lung cancer cell line is correlated to elevated expression of glutathione-linked detoxification enzymes. Carcinogenesis 1994, 15, 1167-1173. [CrossRef] [PubMed]

117. Tew, K.D. Glutathione-associated Enzymes in Anticancer Drug Resistance. Cancer Res. 1994, 54, 4313-4320. [CrossRef] [PubMed]

118. Tew, K.D.; Gaté, L. Glutathione S-transferases as emerging therapeutic targets. Expert Opin. Ther. Targets 2001, 5, 477-489. [CrossRef]

119. Sau, A.; Pellizzari Tregno, F.; Valentino, F.; Federici, G.; Caccuri, A.M. Glutathione transferases and development of new principles to overcome drug resistance. Arch. Biochem. Biophys. 2010, 500, 116-122. [CrossRef]

120. Awasthi, Y.C.; Singh, S.V.; Ahmad, H.; Moller, P.C. Immunocytochemical evidence for the expression of GST1, GST2, and GST3 gene loci for glutathione S-transferase in human lung. Lung 1987, 165, 323-332. [CrossRef]

121. Illio, C.D.; Boccio, G.D.; Aceto, A.; Casaccia, R.; Mucilli, F.; Federici, G. Elevation of glutathione transferase activity in human lung tumor. Carcinogenesis 1988, 9, 335-340. [CrossRef] [PubMed]

122. Meijerman, I.; Beijnen, J.H.; Schellens, J.H.M. Combined action and regulation of phase II enzymes and multidrug resistance proteins in multidrug resistance in cancer. Cancer Treat. Rev. 2008, 34, 505-520. [CrossRef]

123. Homolya, L.; Váradi, A.; Sarkadi, B. Multidrug resistance-associated proteins: Export pumps for conjugates with glutathione, glucuronate or sulfate. BioFactors 2003, 17, 103-114. [CrossRef] [PubMed]

124. Jain, N.; Lam, Y.M.; Pym, J.; Campling, B.G. Mechanisms of resistance of human small cell lung cancer lines selected in VP-16 and cisplatin. Cancer 1996, 77, 1797-1808. [CrossRef]

125. Hospers, G.A.P.; Meuer, C.; De Leij, L.; Uges, D.R.A.; Mulder, N.H.; De Vries, E.G.E. A study of human small-cell lung carcinoma (hSCLC) cell lines with different sensitivities to detect relevant mechanisms of cisplatin (CDDP) resistance. Int. J. Cancer 1990, 46, 138-144. [CrossRef] [PubMed]

126. Moritaka, T.; Kiura, K.; Ueoka, H.; Tabata, M.; Segawa, Y.; Shibayama, T.; Takigawa, N.; Ohnoshi, T.; Harada, M. Cisplatin-resistant human small cell lung cancer cell line shows collateral sensitivity to vinca alkaloids. Anticancer Res. 1998, 18, 927-933. [PubMed] 
127. Zhan, M.C.; Liu, X.Y. Schedule-dependent reversion of cisplatin resistance by 5-fluorouracil in a cisplatin-resistant human lung adenocarcinoma cell line A549DDP. Chin. Med. J. (Engl.) 1999, 112, 336-339.

128. Chio, I.I.C.; Tuveson, D.A. ROS in Cancer: The Burning Question. Trends. Mol. Med. 2017, 23, 411-429. [CrossRef]

129. No, J.H.; Kim, Y.-B.; Song, Y.S. Targeting Nrf2 Signaling to Combat Chemoresistance. J. Cancer Prev. 2014, 19, 11-117. [CrossRef]

130. Zhang, P.; Singh, A.; Yegnasubramanian, S.; Esopi, D.; Kombairaju, P.; Bodas, M.; Wu, H.; Bova, S.; Biswal, S. Loss of kelch-like ECH-associated protein 1 function in prostate cancer cells causes chemoresistance and radioresistance and promotes tumor growth. Mol. Cancer Ther. 2010, 9, 336-346. [CrossRef]

131. Huang, Y.; Dai, Z.; Barbacioru, C.; Sadée, W. Cystine-glutamate transporter SLC7A11 in cancer chemosensitivity and chemoresistance. Cancer Res. 2005, 65, 7446-7454. [CrossRef] [PubMed]

132. Okuno, S.; Sato, H.; Kuriyama-Matsumura, K.; Tamba, M.; Wang, H.; Sohda, S.; Hamada, H.; Yoshikawa, H.; Kondo, T.; Bannai, S. Role of cystine transport in intracellular glutathione level and cisplatin resistance in human ovarian cancer cell lines. Br. J. Cancer 2003, 88, 951-956. [CrossRef] [PubMed]

133. Liu, Y.; Li, Q.; Zhou, L.; Xie, N.; Nice, E.C.; Zhang, H.; Huang, C.; Lei, Y. Cancer drug resistance: Redox resetting renders a way. Oncotarget 2016, 7, 42740-42761. [CrossRef] [PubMed]

134. Minotti, G.; Menna, P.; Salvatorelli, E.; Cairo, G.; Gianni, L. Anthracyclines: Molecular advances and pharmacologie developments in antitumor activity and cardiotoxicity. Pharmacol. Rev. 2004, 56, 185-229. [CrossRef]

135. Ilizarov, A.M.; Koo, H.C.; Kazzaz, J.A.; Mantell, L.L.; Li, Y.; Bhapat, R.; Pollack, S.; Horowitz, S.; Davis, J.M. Overexpression of manganese superoxide dismutase protects lung epithelial cells against oxidant injury. Am. J. Respir. Cell Mol. Biol. 2001, 24, 436-441. [CrossRef]

136. Kinnula, K.; Linnainmaa, K.; Raivio, K.O.; Kinnula, V.L. Endogenous antioxidant enzymes and glutathione S-transferase in protection of mesothelioma cells against hydrogen peroxide and epirubicin toxicity. Br. J. Cancer 1998, 77, 1097-1102. [CrossRef]

137. Sluiter, W.J.; Mulder, N.H.; Timmer-Bosscha, H.; Jan-Meersma, G.; de Vries, E.G.E. Relationship of Cellular Glutathione to the Cytotoxicity and Resistance of Seven Platinum Compounds. Cancer Res. 1992, 52, 6885-6889.

138. Alexandre, J.; Batteux, F.; Nicco, C.; Chéreau, C.; Laurent, A.; Guillevin, L.; Weill, B.; Goldwasser, F. Accumulation of hydrogen peroxide is an early and crucial step for paclitaxel-induced cancer cell death both in vitro and in vivo. Int. J. Cancer 2006, 119, 41-48. [CrossRef]

139. Llobet, D.; Eritja, N.; Encinas, M.; Sorolla, A.; Yeramian, A.; Schoenenberger, J.A.; Llombart-Cussac, A.; Marti, R.M.; Matias-Guiu, X.; Dolcet, X. Antioxidants block proteasome inhibitor function in endometrial carcinoma cells. Anticancer Drugs 2008, 19, 115-124. [CrossRef]

140. Bairati, I.; Meyer, F.; Gélinas, M.; Fortin, A.; Nabid, A.; Brochet, F.; Mercier, J.P.; Têtu, B.; Harel, F.; Abdous, B.; et al. Randomized trial of antioxidant vitamins to prevent acute adverse effects of radiation therapy in head and neck cancer patients. J. Clin. Oncol. 2005, 23, 5805-5813. [CrossRef]

141. Schwartz, P.M.; Moir, R.D.; Hyde, C.M.; Turek, P.J.; Handschumacher, R.E. Role of uridine phosphorylase in the anabolism of 5-fluorouracil. Biochem. Pharmacol. 1985, 34, 3585-3589. [CrossRef]

142. Malet-Martino, M. Clinical Studies of Three Oral Prodrugs of 5-Fluorouracil (Capecitabine, UFT, S-1): A Review. Oncologist 2002, 7, 288-323. [CrossRef] [PubMed]

143. Kosuri, K.V.; Wu, X.; Wang, L.; Villalona-Calero, M.A.; Otterson, G.A. An epigenetic mechanism for capecitabine resistance in mesothelioma. Biochem. Biophys. Res. Commun. 2010, 15, 1465-1470. [CrossRef] [PubMed]

144. O’Hagan, H.M.; Wang, W.; Sen, S.; DeStefano Shields, C.; Lee, S.S.; Zhang, Y.W.; Clements, E.G.; Cai, Y.; Van Neste, L.; Easwaran, H.; et al. Oxidative Damage Targets Complexes Containing DNA Methyltransferases, SIRT1, and Polycomb Members to Promoter CpG Islands. Cancer Cell 2011, 20, 606-619. [CrossRef] [PubMed]

145. Yueh, M.F.; Tukey, R.H. Nrf2-Keap1 Signaling pathway regulates human UGT1A1 expression in vitro and in transgenic UGT1 mice. J. Biol. Chem. 2007, 282, 8749-8758. [CrossRef]

146. Bélanger, A.S.; Tojcic, J.; Harvey, M.; Guillemette, C. Regulation of UGT1A1 and HNF1 transcription factor gene expression by DNA methylation in colon cancer cells. BMC Mol. Biol. 2010, 11, 9. [CrossRef] [PubMed] 
147. Barabas, K.; Milner, R.; Lurie, D.; Adin, C. Cisplatin: A review of toxicities and therapeutic applications. Vet. Comp. Oncol. 2008, 6, 1-18. [CrossRef]

148. Gossage, L.; Madhusudan, S. Current status of excision repair cross complementing-group 1 (ERCC1) in cancer. Cancer Treat. Rev. 2007, 33, 565-577. [CrossRef]

149. Steffensen, K.D.; Waldstrøm, M.; Jakobsen, A. The relationship of platinum resistance and ERCC1 protein expression in epithelial ovarian cancer. Int. J. Gynecol. Cancer 2009, 19, 820-825. [CrossRef]

150. Lord, R.V.N.; Brabender, J.; Gandara, D.; Alberola, V.; Camps, C.; Domine, M.; Cardenal, F.; Sánchez, J.M.; Gumerlock, P.H.; Tarón, M.; et al. Low ERRC1 expression correlates with prolonged survival after cisplatin plus gemcitabine chemotherapy in non-small cell lung cancer. Clin. Cancer Res. 2002, 8, 2286-2291.

151. Rosell, R.; Lord, R.V.N.; Taron, M.; Reguart, N. DNA repair and cisplatin resistance in non-small-cell lung cancer. Lung Cancer 2002, 38, 217-227. [CrossRef]

152. Li, G.M. Mechanisms and functions of DNA mismatch repair. Cell Res. 2008, 18, 85-98. [CrossRef] [PubMed]

153. Topping, R.P.; Wilkinson, J.C.; Scarpinato, D. Mismatch repair protein deficiency compromises cisplatin-induced apoptotic signaling. J. Biol. Chem. 2009, 284, 14029-14039. [CrossRef] [PubMed]

154. Adhikari, S.; Choudhury, S.; Mitra, P.; Dubash, J.; Sajankila, S.; Roy, R. Targeting Base Excision Repair for Chemosensitization. Anticancer Agents. Med. Chem. 2008, 8, 351-357. [CrossRef]

155. Housman, G.; Byler, S.; Heerboth, S.; Lapinska, K.; Longacre, M.; Snyder, N.; Sarkar, S. Drug resistance in cancer: An overview. Cancers (Basel) 2014, 6, 1769-1792. [CrossRef]

156. Fennel, D.A. Bcl-2 as a target for overcoming chemoresistance in small-cell lung cancer. Clin. Lung Cancer 2003, 4, 307-313. [CrossRef]

157. Okouoyo, S.; Herzer, K.; Ucur, E.; Mattern, J.; Krammer, P.H.; Debatin, K.M.; Herr, I. Rescue of death receptor and mitochondrial apoptosis signaling in resistant human NSCLC in vivo. Int. J. Cancer 2004, 108, 580-587. [CrossRef]

158. Yang, L.; Mashima, T.; Sato, S.; Mochizuki, M.; Sakamoto, H.; Yamori, T.; Oh-hara, T.; Tsuruo, T. Predominant suppression of apoptosome by inhibitor of apoptosis protein in non-small cell lung cancer H460 cells: Therapeutic effect of a novel polyarginine-conjugated Smac peptide. Cancer Res. 2003, 63, 831-837.

159. Monzó, M.; Rosell, R.; Felip, E.; Astudillo, J.; Sánchez, J.J.; Maestre, J.; Martín, C.; Font, A.; Barnadas, A.; Abad, A. A novel anti-apoptosis gene: Re-expression of survivin messenger RNA as a prognosis marker in non-small-cell lung cancers. J. Clin. Oncol. 1999, 17, 2100-2104. [CrossRef]

160. Shrivastav, M.; De Haro, L.P.; Nickoloff, J.A. Regulation of DNA double-strand break repair pathway choice. Cell Res. 2008, 18, 134-147. [CrossRef]

161. Srivastava, R.K.; Sasaki, C.Y.; Hardwick, J.M.; Longo, D.L. Bcl-2-mediated drug resistance: Inhibition of apoptosis by blocking nuclear factor of activated T lymphocytes (NFAT)-induced fas ligand transcription. J. Exp. Med. 1999, 190, 253-265. [CrossRef] [PubMed]

162. Facchinetti, F.; Proto, C.; Minari, R.; Garassino, M.; Tiseo, M. Mechanisms of Resistance to Target Therapies in Non-Small Cell Lung Cancer. Handb. Exp. Pharmacol. 2018, 249, 63-89. [PubMed]

163. Rosell, R.; Moran, T.; Queralt, C.; Porta, R.; Cardenal, F.; Camps, C.; Majem, M.; Lopez-Vivanco, G.; Isla, D.; Provencio, M.; et al. Screening for epidermal growth factor receptor mutations in lung cancer. N. Engl. J. Med. 2009, 958-967. [CrossRef] [PubMed]

164. Yang, J.C.H.; Wu, Y.L.; Schuler, M.; Sebastian, M.; Popat, S.; Yamamoto, N.; Zhou, C.; Hu, C.P.; O’Byrne, K.; Feng, J.; et al. Afatinib versus cisplatin-based chemotherapy for EGFR mutation-positive lung adenocarcinoma (LUX-Lung 3 and LUX-Lung 6): Analysis of overall survival data from two randomised, phase 3 trials. Lancet Oncol. 2015, 141-151. [CrossRef]

165. Lynch, T.J.; Bell, D.W.; Sordella, R.; Gurubhagavatula, S.; Okimoto, R.A.; Brannigan, B.W.; Harris, P.L.; Haserlat, S.M.; Supko, J.G.; Haluska, F.G.; et al. Activating Mutations in the Epidermal Growth Factor Receptor Underlying Responsiveness of Non-Small-Cell Lung Cancer to Gefitinib. N. Engl. J. Med. 2004, 1, S24-S31. [CrossRef]

166. Godin-Heymann, N.; Ulkus, L.; Brannigan, B.W.; McDermott, U.; Lamb, J.; Maheswaran, S.; Settleman, J.; Haber, D.A. The T790M "gatekeeper" mutation in EGFR mediates resistance to low concentrations of an irreversible EGFR inhibitor. Mol. Cancer Ther. 2008. [CrossRef]

167. Sequist, L.V.; Waltman, B.A.; Dias-Santagata, D.; Digumarthy, S.; Turke, A.B.; Fidias, P.; Bergethon, K.; Shaw, A.T.; Gettinger, S.; Cosper, A.K.; et al. Genotypic and histological evolution of lung cancers acquiring resistance to EGFR inhibitors. Sci. Transl. Med. 2011, 75ra26. [CrossRef] 
168. Engelman, J.A.; Zejnullahu, K.; Mitsudomi, T.; Song, Y.; Hyland, C.; Park, J.O.; Lindeman, N.; Gale, C.-M.; Zhao, X.; Christensen, J.; et al. MET amplification leads to gefitinib resistance in lung cancer by activating ERBB3 signaling. Science 2007, 316, 1039-1043. [CrossRef]

169. Turke, A.B.; Zejnullahu, K.; Wu, Y.L.; Song, Y.; Dias-Santagata, D.; Lifshits, E.; Toschi, L.; Rogers, A.; Mok, T.; Sequist, L.; et al. Preexistence and Clonal Selection of MET Amplification in EGFR Mutant NSCLC. Cancer Cell 2010, 17, 77-88. [CrossRef]

170. Yu, H.A.; Arcila, M.E.; Rekhtman, N.; Sima, C.S.; Zakowski, M.F.; Pao, W.; Kris, M.G.; Miller, V.A.; Ladanyi, M.; Riely, G.J. Analysis of tumor specimens at the time of acquired resistance to EGFR-TKI therapy in 155 patients with EGFR-mutant lung cancers. Clin. Cancer Res. 2013, 2240-2247. [CrossRef]

171. Takezawa, K.; Pirazzoli, V.; Arcila, M.E.; Nebhan, C.A.; Song, X.; de Stanchina, E.; Ohashi, K.; Janjigian, Y.Y.; Spitzler, P.J.; Melnick, M.A.; et al. HER2 amplification: A potential mechanism of acquired resistance to egfr inhibition in EGFR -mutant lung cancers that lack the second-site EGFR T790M mutation. Cancer Discov. 2012, 922-933. [CrossRef] [PubMed]

172. Pao, W.; Wang, T.Y.; Riely, G.J.; Vincent, A.M.; Qiulu, P.; Marc, L.; Maureen, F.Z.; Robert, T.H.; Mark, G.K.; Harold, E.V. KRAS mutations and primary resistance of lung adenocarcinomas to gefitinib or erlotinib. PLoS Med. 2005. [CrossRef] [PubMed]

173. Milella, M.; Falcone, I.; Conciatori, F.; Incani, U.C.; Curatolo, A.D.; Inzerilli, N.; Nuzzo, C.M.A.; Vaccaro, V.; Vari, S.; Cognetti, F.; et al. PTEN: Multiple functions in human malignant tumors. Front. Oncol. 2015, 5. [CrossRef] [PubMed]

174. Cantley, L.C.; Neel, B.G. New insights into tumor suppression: PTEN suppresses tumor formation by restraining the phosphoinositide 3-kinase/AKT pathway. Proc. Natl. Acad. Sci. USA 1999, 96, 4240-4245. [CrossRef] [PubMed]

175. Sos, M.L.; Koker, M.; Weir, B.A.; Heynck, S.; Rabinovsky, R.; Zander, T.; Seeger, J.M.; Weiss, J.; Fischer, F.; Frommolt, P.; et al. PTEN loss contributes to erlotinib resistance in EGFR-mutant lung cancer by activation of akt and EGFR. Cancer Res. 2009, 69, 3256-3261. [CrossRef] [PubMed]

176. Thomson, S.; Buck, E.; Petti, F.; Griffin, G.; Brown, E.; Ramnarine, N.; Iwata, K.K.; Gibson, N.; Haley, J.D. Epithelial to mesenchymal transition is a determinant of sensitivity of non-small-cell lung carcinoma cell lines and xenografts to epidermal growth factor receptor inhibition. Cancer Res. 2005, 9455-9462. [CrossRef]

177. Okon, I.S.; Coughlan, K.A.; Zhang, M.; Wang, Q.; Zou, M.H. Gefitinib-mediated reactive oxygen specie (ROS) instigates mitochondrial dysfunction and drug resistance in lung cancer cells. J Biol Chem 2015, 290, 9101-9110. [CrossRef]

178. Haratani, K.; Hayashi, H.; Watanabe, S.; Kaneda, H.; Yoshida, T.; Takeda, M.; Shimizu, T.; Nakagawa, K. Two cases of EGFR mutationpositive lung adenocarcinoma that transformed into squamous cell carcinoma: Successful treatment of one case with rociletinib. Ann. Oncol. 2016, 27, 200-202. [CrossRef]

179. Minari, R.; Bordi, P.; Tiseo, M. Third-generation epidermal growth factor receptor-tyrosine kinase inhibitors in T790M-positive non-small cell lung cancer: Review on emerged mechanisms of resistance. Transl. Lung Cancer Res. 2016, 5, 695-708. [CrossRef]

180. Thress, K.S.; Paweletz, C.P.; Felip, E.; Cho, B.C.; Stetson, D.; Dougherty, B.; Lai, Z.; Markovets, A.; Vivancos, A.; Kuang, Y.; et al. Acquired EGFR C797S mutation mediates resistance to AZD9291 in non-small cell lung cancer harboring EGFR T790M. Nat. Med. 2015, 560-562. [CrossRef]

181. Niederst, M.J.; Hu, H.; Mulvey, H.E.; Lockerman, E.L.; Garcia, A.R.; Piotrowska, Z.; Sequist, L.V.; Engelman, J.A. The allelic context of the C797S mutation acquired upon treatment with third-generation EGFR inhibitors impacts sensitivity to subsequent treatment strategies. Clin. Cancer Res. 2015, 3924-3933. [CrossRef] [PubMed]

182. Yang, T.; Ng, W.H.; Chen, H.; Chomchopbun, K.; Huynh, T.H.; Go, M.L.; Kon, O.L. Mitochondrial-Targeting MET Kinase Inhibitor Kills Erlotinib-Resistant Lung Cancer Cells. ACS Med. Chem. Lett. 2016, 7, 807-812. [CrossRef] [PubMed]

183. Qian, X.; Li, J.; Ding, J.; Wang, Z.; Zhang, W.; Hu, G. Erlotinib activates mitochondrial death pathways related to the production of reactive oxygen species in the human non-small cell lung cancer cell line a549. Clin. Exp. Pharmacol. Physiol. 2009, 35, 487-494. [CrossRef] [PubMed]

184. Shan, F.; Shao, Z.; Jiang, S.; Cheng, Z. Erlotinib induces the human non-small-cell lung cancer cells apoptosis via activating ROS-dependent JNK pathways. Cancer Med. 2016, 5, 3166-3175. [CrossRef] 
185. Choi, Y.L.; Soda, M.; Yamashita, Y.; Ueno, T.; Takashima, J.; Nakajima, T.; Yatabe, Y.; Takeuchi, K.; Hamada, T.; Haruta, H.; et al. EML4-ALK mutations in lung cancer that confer resistance to ALK inhibitors. N. Engl. J. Med. 2010, 1734-1739. [CrossRef]

186. Gainor, J.F.; Dardaei, L.; Yoda, S.; Friboulet, L.; Leshchiner, I.; Katayama, R.; Dagogo-Jack, I.; Gadgeel, S.; Schultz, K.; Singh, M.; et al. Molecular mechanisms of resistance to first- and second-generation ALK inhibitors in ALK -rearranged lung cancer. Cancer Discov. 2016, 1118-1133. [CrossRef]

187. Mengoli, M.C.; Barbieri, F.; Bertolini, F.; Tiseo, M.; Rossi, G. K-RAS mutations indicating primary resistance to crizotinib in ALK-rearranged adenocarcinomas of the lung: Report of two cases and review of the literature. Lung Cancer 2016, 55-58. [CrossRef]

188. Doebele, R.C.; Pilling, A.B.; Aisner, D.L.; Kutateladze, T.G.; Le, A.T.; Weickhardt, A.J.; Kondo, K.L.; Linderman, D.J.; Heasley, L.E.; Franklin, W.A.; et al. Mechanisms of resistance to crizotinib in patients with ALK gene rearranged non-small cell lung cancer. Clin. Cancer Res. 2012. [CrossRef]

189. Cargnelutti, M.; Corso, S.; Pergolizzi, M.; Mévellec, L.; Aisner, D.L.; Dziadziuszko, R.; Varella-Garcia, M.; Comoglio, P.M.; Doebele, R.C.; Vialard, J.; et al. Activation of RAS family members confers resistance to ROS1 targeting drugs. Oncotarget 2015, 5182-5194. [CrossRef]

190. Shaw, A.T.; Felip, E.; Bauer, T.M.; Besse, B.; Navarro, A.; Postel-Vinay, S.; Gainor, J.F.; Johnson, M.; Dietrich, J.; James, L.P.; et al. Lorlatinib in non-small-cell lung cancer with ALK or ROS1 rearrangement: An international, multicentre, open-label, single-arm first-in-man phase 1 trial. Lancet Oncol. 2017, 18, 1590-1599. [CrossRef]

191. Doherty, K.R.; Wappel, R.L.; Talbert, D.R.; Trusk, P.B.; Moran, D.M.; Kramer, J.W.; Brown, A.M.; Shell, S.A.; Bacus, S. Multi-parameter in vitro toxicity testing of crizotinib, sunitinib, erlotinib, and nilotinib in human cardiomyocytes. Toxicol. Appl. Pharmacol. 2013, 272, 245-255. [CrossRef] [PubMed]

192. Loges, S.; Schmidt, T.; Carmeliet, P. Mechanisms of resistance to anti-angiogenic therapy and development of third-generation anti-angiogenic drug candidates. Genes Cancer 2010, 1, 12-25. [CrossRef] [PubMed]

193. Niu, G.; Chen, X. Vascular Endothelial Growth Factor as an Anti-Angiogenic Target for Cancer Therapy. Curr. Drug Targets 2010, 11, 1000-1017. [CrossRef] [PubMed]

194. Kawakami, T.; Tokunaga, T.; Hatanaka, H.; Kijima, H.; Yamazaki, H.; Abe, Y.; Osamura, Y.; Inoue, H.; Ueyama, Y.; Nakamura, M. Neuropilin 1 and neuropilin 2 co-expression is significantly correlated with increased vascularity and poor prognosis in nonsmall cell lung carcinoma. Cancer 2002, 2196-2201. [CrossRef] [PubMed]

195. Galluzzi, L.; Kepp, O.; Heiden, M.G.V.; Kroemer, G. Metabolic targets for cancer therapy. Nat. Rev. Drug Discov. 2013, 829-846. [CrossRef] [PubMed]

196. Zaal, E.A.; Berkers, C.R. The influence of metabolism on drug response in cancer. Front. Oncol. 2018, 8, 1-15. [CrossRef]

197. Wangpaichitr, M.; Wu, C.; Li, Y.Y.; Nguyen, D.J.M.; Kandemir, H.; Shah, S.; Chen, S.; Feun, L.G.; Prince, J.S.; Kuo, M.T.; et al. Exploiting ROS and metabolic differences to kill cisplatin resistant lung cancer. Oncotarget 2017, 49275-49292. [CrossRef]

198. Wangpaichitr, M.; Sullivan, E.J.; Theodoropoulos, G.; Wu, C.; You, M.; Feun, L.G.; Lampidis, T.J.; Kuo, M.T.; Savaraj, N. The relationship of thioredoxin-1 and cisplatin resistance: Its impact on ROS and oxidative metabolism in lung cancer cells. Mol. Cancer Ther. 2012, 604-615. [CrossRef]

199. Wangpaichitr, M.; Wu, C.; You, M.; Maher, J.; Dinh, V.; Feun, L.; Savaraj, N. $\mathrm{N}^{\prime} 1, \mathrm{~N}^{\prime} 3$-Dimethyl-N'1,N'3-bis(phenylcarbonothioyl) Propanedihydrazide (Elesclomol) Selectively Kills Cisplatin Resistant Lung Cancer Cells through Reactive Oxygen Species (ROS). Cancers 2009, 23-38. [CrossRef]

200. Kuo, M.T.; Chen, H.H.W. Role of glutathione in the regulation of cisplatin resistance in cancer chemotherapy. Met. Based Drugs 2010, 1-7. [CrossRef]

201. Sullivan, E.J.; Kurtoglu, M.; Brenneman, R.; Liu, H.; Lampidis, T.J. Targeting cisplatin-resistant human tumor cells with metabolic inhibitors. Cancer Chemother. Pharmacol. 2014, 417-427. [CrossRef]

202. Fadaka, A.; Ajiboye, B.; Ojo, O.; Adewale, O.; Olayide, I.; Emuowhochere, R. Biology of glucose metabolization in cancer cells. J. Oncol. Sci. 2017, 3, 45-51. [CrossRef]

203. Leyton, J.; Latigo, J.R.; Perumal, M.; Dhaliwal, H.; He, Q.; Aboagye, E.O. Early detection of tumor response to chemotherapy by $3^{\prime}$-deoxy- $3^{\prime}-[18 \mathrm{~F}]$ fluorothymidine positron emission tomography: The effect of cisplatin on a fibrosarcoma tumor model in vivo. Cancer Res. 2005, 65, 4202-4210. [CrossRef] [PubMed] 
204. Jeon, J.H.; Kim, D.K.; Shin, Y.; Kim, H.Y.; Song, B.; Lee, E.Y.; Kim, J.K.; You, H.J.; Cheong, H.; Shin, D.H.; et al. Migration and invasion of drug-resistant lung adenocarcinoma cells are dependent on mitochondrial activity. Exp. Mol. Med. 2016, 48, e277. [CrossRef] [PubMed]

205. Miller, R.G.; Mitchell, J.D.; Lyon, M.; Moore, D.H. Riluzole for amyotrophic lateral sclerosis (ALS)/motor neuron disease (MND). Amyotroph. Lateral Scler. Other Mot Neuron Disords 2003, 4, 191-206. [CrossRef]

206. Namkoong, J.; Shin, S.S.; Hwa, J.L.; Marín, Y.E.; Wall, B.A.; Goydos, J.S.; Chen, S. Metabotropic glutamate receptor 1 and glutamate signaling in human melanoma. Cancer Res. 2007, 2298-2305. [CrossRef] [PubMed]

207. Yip, D.; Le, M.N.; Chan, J.L.K.; Lee, J.H.; Mehnert, J.A.; Yudd, A.; Kempf, J.; Shih, W.J.; Chen, S.; Goydos, J.S. A phase 0 trial of riluzole in patients with resectable stage III and IV melanoma. Clin. Cancer Res. 2009, 3896-3902. [CrossRef] [PubMed]

208. Liu, H.; Savaraj, N.; Priebe, W.; Lampidis, T.J. Hypoxia increases tumor cell sensitivity to glycolytic inhibitors: A strategy for solid tumor therapy (Model C). Biochem. Pharmacol. 2002, 64, 1745-1751. [CrossRef]

209. Maher, J.C.; Krishan, A.; Lampidis, T.J. Greater cell cycle inhibition and cytotoxicity induced by 2-deoxy-D-glucose in tumor cells treated under hypoxic vs aerobic conditions. Cancer Chemother. Pharmacol. 2004, 53, 116-122. [CrossRef]

210. Liu, Y.; He, C.; Huang, X. Metformin partially reverses the carboplatin-resistance in NSCLC by inhibiting glucose metabolism. Oncotarget 2017, 8, 75206-75216. [CrossRef]

211. Li, L.; Han, R.; Xiao, H.; Lin, C.; Wang, Y.; Liu, H.; Li, K.; Chen, H.; Sun, F.; Yang, Z.; et al. Metformin sensitizes EGFR-TKI-Resistant human lung cancer cells in vitro and in vivo through inhibition of IL-6 signaling and EMT reversal. Clin. Cancer Res. 2014, 2714-2726. [CrossRef] [PubMed]

212. Riaz, M.A.; Sak, A.; Erol, Y.B.; Groneberg, M.; Thomale, J.; Stuschke, M. Metformin enhances the radiosensitizing effect of cisplatin in non-small cell lung cancer cell lines with different cisplatin sensitivities. Sci. Rep. 2019, 9, 1-16. [CrossRef] [PubMed]

213. Raez, L.E.; Papadopoulos, K.; Ricart, A.D.; Chiorean, E.G.; Dipaola, R.S.; Stein, M.N.; Rocha Lima, C.M.; Schlesselman, J.J.; Tolba, K.; Langmuir, V.K.; et al. A phase i dose-escalation trial of 2-deoxy-d-glucose alone or combined with docetaxel in patients with advanced solid tumors. Cancer Chemother. Pharmacol. 2013, 71, 523-530. [CrossRef] [PubMed]

214. Zamble, D.B.; Lippard, S.J. Cisplatin and DNA repair in cancer chemotherapy. Trends Biochem. Sci. 1995, 435-439. [CrossRef]

215. Pernicova, I.; Korbonits, M. Metformin-Mode of action and clinical implications for diabetes and cancer. Nat. Rev. Endocrinol. 2014, 10, 143-156. [CrossRef]

216. Snima, K.; Pillai, P.; Cherian, A.; Nair, S.; Lakshmanan, V.-K. Anti-diabetic Drug Metformin: Challenges and Perspectives for Cancer Therapy. Curr. Cancer Drug Targets 2014, 727-736. [CrossRef]

217. Yousef, M.; Tsiani, E. Metformin in lung cancer: Review of in vitro and in vivo animal studies. Cancers 2017. [CrossRef]

218. Handschin, C.; Spiegelman, B.M. Peroxisome proliferator-activated receptor $\gamma$ coactivator 1 coactivators, energy homeostasis, and metabolism. Endocr. Rev. 2006, 27, 728-735. [CrossRef]

219. Sabharwal, S.S.; Schumacker, P.T. Mitochondrial ROS in cancer: Initiators, amplifiers or an Achilles' heel? Nat. Rev. Cancer 2014, 14, 709-721. [CrossRef]

220. Cruz-Bermúdez, A.; Laza-Briviesca, R.; Vicente-Blanco, R.J.; García-Grande, A.; Coronado, M.J.; Laine-Menéndez, S.; Palacios-Zambrano, S.; Moreno-Villa, M.R.; Ruiz-Valdepeñas, A.M.; Lendinez, C.; et al. Cisplatin resistance involves a metabolic reprogramming through ROS and PGC-1 $\alpha$ in NSCLC which can be overcome by OXPHOS inhibition. Free Radic. Biol. Med. 2019, 135, 167-181. [CrossRef]

221. Yuan, S.; Qiao, T.; Zhuang, X.; Chen, W.; Xing, N.; Zhang, Q. Knockdown of the M2 Isoform of Pyruvate Kinase (PKM2) with shRNA Enhances the Effect of Docetaxel in Human NSCLC Cell Lines In Vitro. Yonsei Med. J. 2016, 57, 1312-1323. [CrossRef] [PubMed]

222. Zhan, L.; Zhang, H.; Zhang, Q.; Woods, C.G.; Chen, Y.; Xue, P.; Dong, J.; Tokar, E.J.; Xu, Y.; Hou, Y.; et al. Regulatory role of KEAP1 and NRF2 in PPAR $\gamma$ expression and chemoresistance in human non-small-cell lung carcinoma cells. Free Radic. Biol. Med. 2012, 53, 758-768. [CrossRef] [PubMed] 
223. Tao, S.; Wang, S.; Moghaddam, S.J.; Ooi, A.; Chapman, E.; Wong, P.K.; Zhang, D.D. Oncogenic KRAS confers chemoresistance by upregulating NRF2. Cancer Res. 2014, 74, 7430-7441. [CrossRef] [PubMed]

224. Apicella, M.; Giannoni, E.; Fiore, S.; Chiarugi, P.; Giordano, S.; Corso, S. Increased Lactate Secretion by Cancer Cells Sustains Non-cell-autonomous Adaptive Resistance to MET and EGFR Targeted Therapies. Cell Metab. 2018, 28, 848-865. [CrossRef] [PubMed]

C 2019 by the authors. Licensee MDPI, Basel, Switzerland. This article is an open access article distributed under the terms and conditions of the Creative Commons Attribution (CC BY) license (http://creativecommons.org/licenses/by/4.0/). 